\title{
Phenology of tree species of tropical moist forest of Uttara Kannada district, Karnataka, India
}

\author{
D M BHAT \\ Centre for Ecological Sciences, Indian Institute of Science, Bangalore 560 012, India \\ MS received 12 June 1991; revised 3 July 1992
}

\begin{abstract}
Phenological observations on tree species in tropical moist forest of Uttara Kannada district $\left(13^{\circ} 55^{\prime}\right.$ to $15^{\circ} 31^{\prime} \mathrm{N}$ lat; $74^{\circ} 9^{\prime}$ to $75^{\circ} 10^{\prime} \mathrm{E}$ long) during the years 1983 1985 revealed that there exists a strong seasonality for leaf flush, leaf drop and reproduction. Young leaves were produced in the pre-monsoon dry period with a peak in February, followed by the expansion of leaves which was completed in March. Abscission of leaves occurred in the post-monsoon winter period with a peak in December. There were two peaks for flowering (December and March), while fruit ripening had a single peak in May-June, preceding the monsoon rainfall. The duration of maturation of leaves was the shortest, while that of full ripening of fruits was the longest. Mature flowers of evergreen species lasted longer than those of deciduous species; in contrast the phenophase of ripe fruits of deciduous species was longer than that of evergreen species.
\end{abstract}

Keywords. Phenology; tree species; tropical moist forest; Western Ghats.

\section{Introduction}

Periodic behaviour of plants in tropical environments has received much attention in recent years. The knowledge of phenology of plants has helped to understand the influence of phenological events on feeding, movement patterns, and sociality of insects, birds and mammals (e.g. Foster 1982b; Leigh and Windsor 1982; Prasad 1983; Wada 1983; Appanah 1985; Coates-Estrada and Estrada 1986). More recently, efforts have been made to discern the importance of general community patterns in leafing, flowering and fruiting for many species, of which particular forest types are composed (Frankie et al 1974a; Lieth 1974; Opler et al 1980). A considerable amount of information is available on the major phenological events of plant species from different parts of tropical America, Africa and south-east Asia including continental India (Santapau 1962; Malaisse 1974; Monasterio and Sarmeinto 1976; Liberman 1982; Rai and Proctor 1986; Steven et al 1987; Bullock and Solis-Magallanes 1990). While the studies on phenology in north-eastern India (Boojh and Ramakrishnan 1982; Shukla and Ramakrishnan 1982, 1984), in Himalaya (Ralhan et al 1985) and in deciduous forest of Bandipur in peninsular India (Prasad and Hegde 1986) do shed light on foliage dynamics, its relation to successional status of a given species, phenodynamics and the variation in the distribution of phenological events, the phenology of tropical moist forest species of Western Ghats region is less understood. The present study describes the phenological patterns in tree species of the Western Ghats district of Uttara Kannada, and the results are compared with those from other tropical sites. 


\section{Materials and methods}

\subsection{Study area}

The district of Uttara Kannada $\left(13^{\circ} 55^{\prime}\right.$ to $15^{\circ} 31^{\prime} \mathrm{N}$ lat; $74^{\circ} 9^{\prime}$ to $75^{\circ} 10^{\prime} \mathrm{E}$ long$)$, comprising an area of $10,200 \mathrm{~km}^{2}$, lies on the west coast of India (figure 1). The hill range of the Western Ghats runs parallel to the coast, rising to a little over $1000 \mathrm{~m}$ above mean sea level. The altitude of the study sites ranged from 50 to $600 \mathrm{~m}$. Topographically the district may be divided into 3 zones: the flat and narrow coast, abruptly rising ridge, and flatter, elevated eastern zone that joins with the Deccan plateau. Climatically the district is tropical. Annual rainfall in the district ranges from $350 \mathrm{~cm}$ near the coast to $500 \mathrm{~cm}$ at some places along the ridge of the hills. The eastern side of the district receives about $120 \mathrm{~cm}$ of rainfall. The maximum

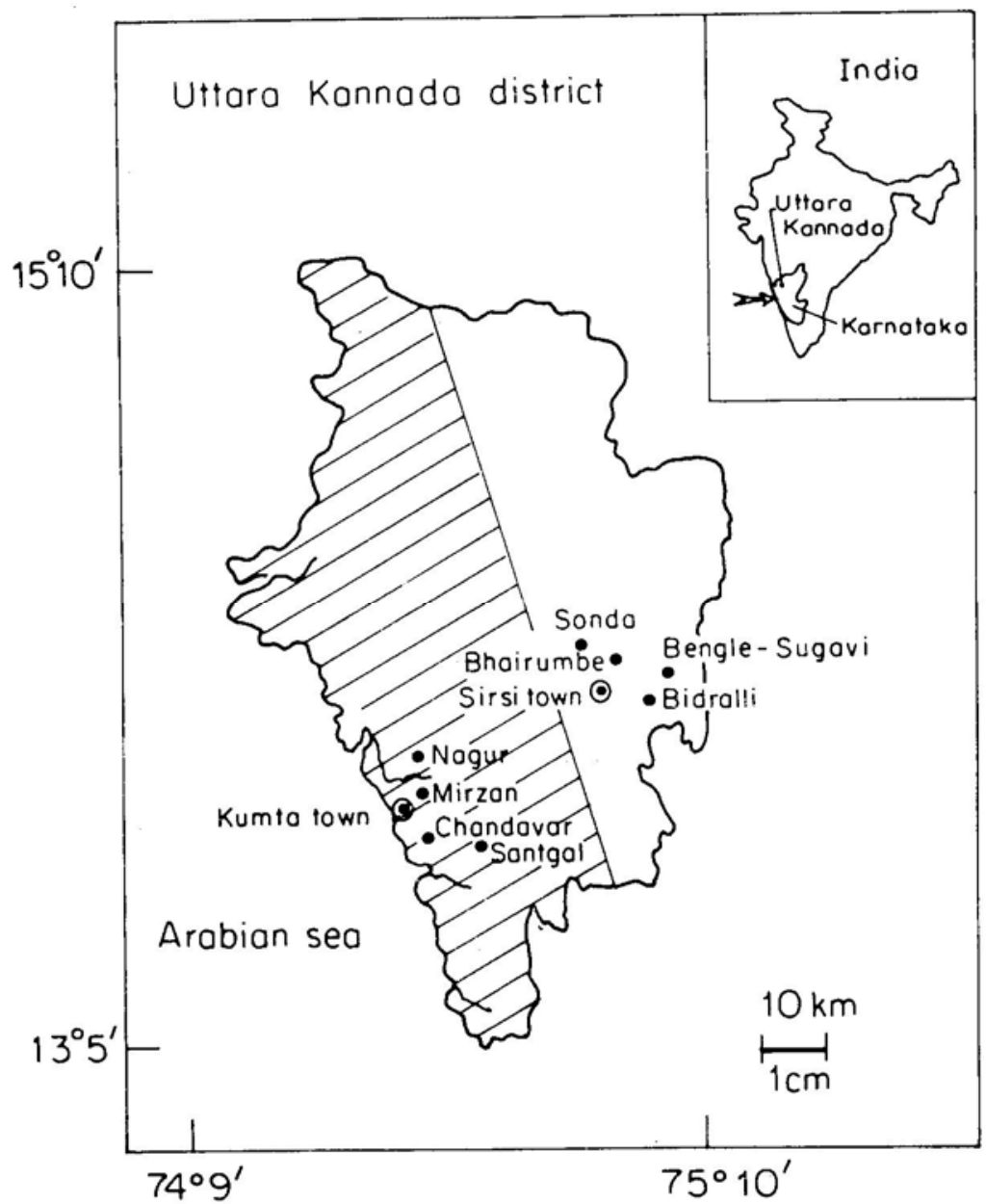

Figure 1. Map of Uttara Kannada district showing broad vegetation types and location of sites.

( 짐) Evergreen/semigreen tract; $(\square)$ secondary/moist deciduous tract. 
temperature in higher elevation (hereafter referred to as above ghat) areas of the district ranges from 25 to $32^{\circ} \mathrm{C}$ while for the coastal region it is 28 to $33^{\circ} \mathrm{C}$. The minimum temperature varies from 13 to $21^{\circ} \mathrm{C}$ and 20 to $25^{\circ} \mathrm{C}$ respectively for above ghat and coastal areas (figure 2). Geologically the district is a transitional zone between the younger basaltic rocks of Deccan trap formation and the older crystalline rocks of Archaean shield of Indian Peninsula. The natural forests are of evergreen/semievergreen type along the slopes, and towards the east of the ridge it is secondary/moist deciduous. Based on the annual rainfall and the vegetation types the district was broadly divided into evergreen/semievergreen zone and drier secondary/moist deciduous zone (figure 1). Table 1 gives sampling localities, their vegetation types and other important characters.
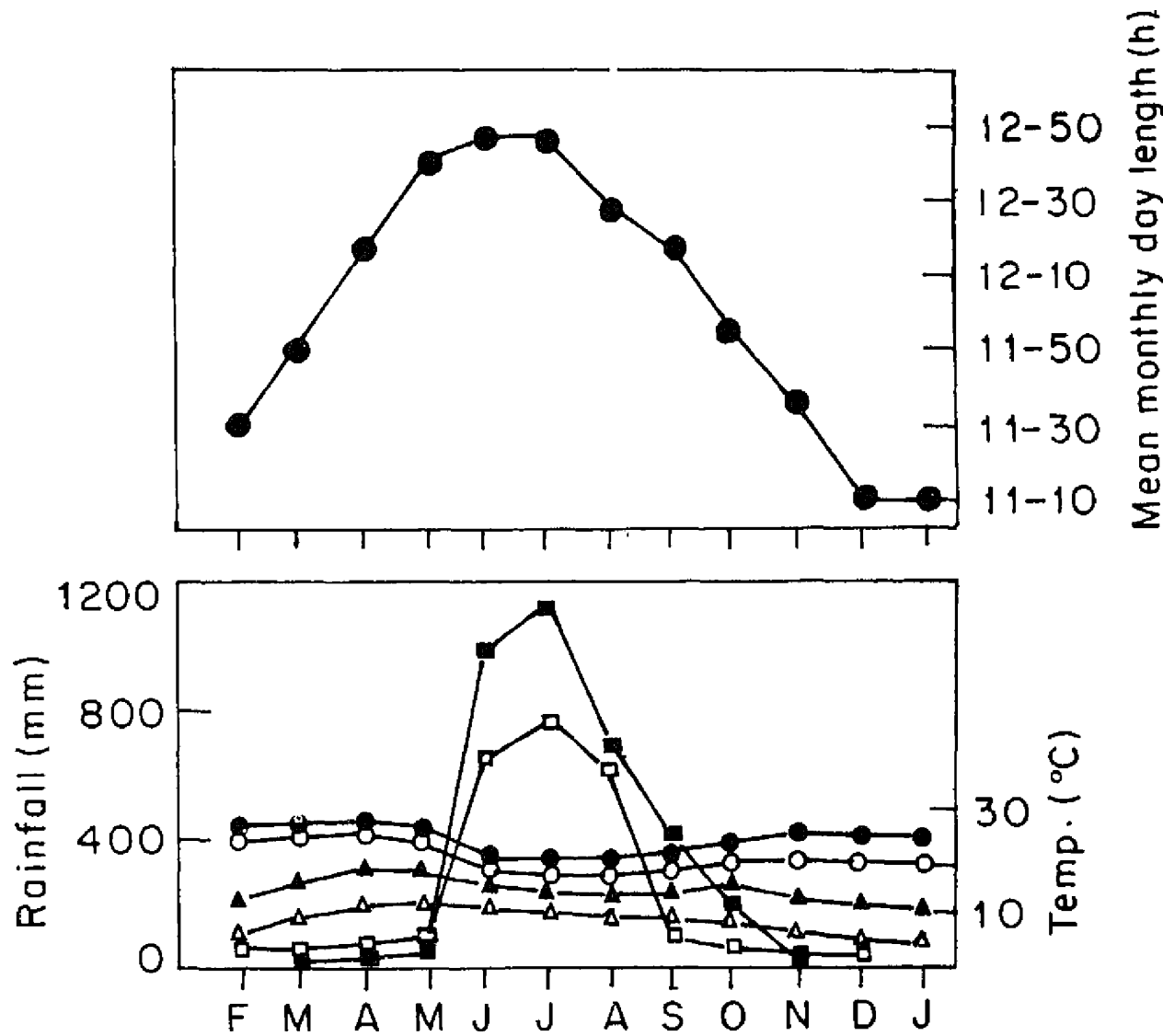

Figure 2. Daylength and climate in Uttara Kannada district.

$(\square, \bigcirc, \Delta)$, Above ghat area; $(\mathbf{\square}, \bullet, \boldsymbol{\Delta})$ coastal area; $(\square, \boldsymbol{\square})$, mean monthly rainfall; $(\mathrm{O}, \bullet)$, mean monthly maximum temperature; $(\Delta, \boldsymbol{\Delta})$, mean monthly minimum temperature.

\subsection{Methods}

Of the 8 one-hectare plots selected for the present study, 4 were from coastal area representing evergreen/semievergreen zone and remaining 4 plots were from above 
Table 1. Some important characteristics of study sites from two different vegetation zones in Uttara Kannada district

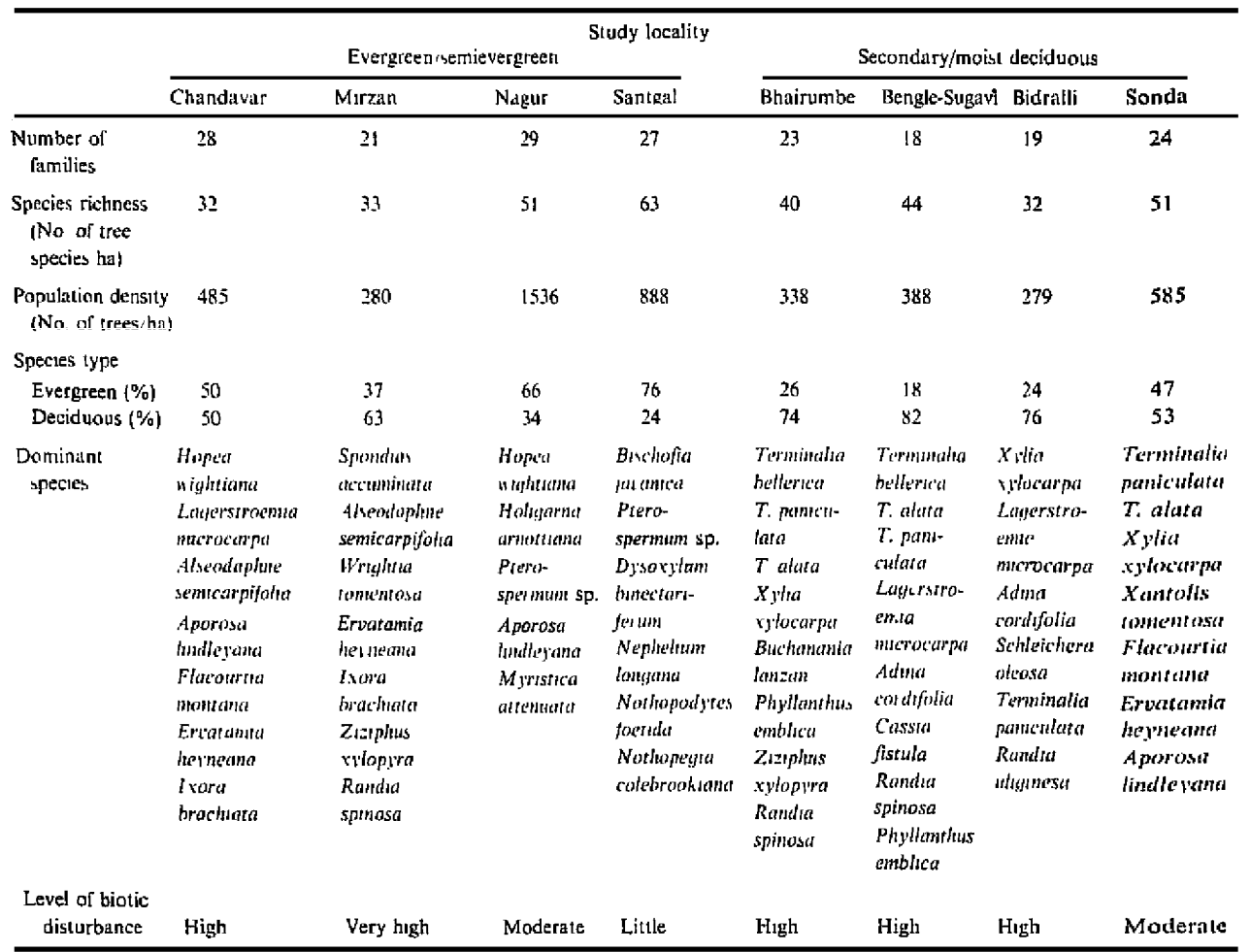

ghat area representing the secondary/moist deciduous zone. All the individuals of tree species with a girth of $10 \mathrm{~cm}$ and above were marked with a metal tag. Each plot was visited once a fortnight from November 1983 to December 1985 to record the changes for the following 9 phenological events: (i) Production of young leaves (YL), (ii) Maturation of leaves (ML), (iii) Abscission of leaves (AL), (iv) Production of young flowers (YF1), (v) Maturation (anthesis) of flowers (MF1), (vi) Abscission of flowers (AF1), (vii) Production of young fruits (YFr), (viii) Maturation of fruits (MFr), and (ix) Ripening of fruits (RFr).

During the fortnightly visits, marked individuals were qualitatively characterized for these 9 phenological events (Prasad and Hegde 1986) and the phenostage of a species was determined by considering the status of majority of individuals. In the case of species represented by only a few individuals, those present in nearby areas were observed to confirm the phenological status of that species. The duration of a phenological event in a species was computed by obtaining the number of days required for the completion of an event from the date of the fortnightly visit when the event was first observed. For each species, interphenophase durations, i.e. periods between successive phenological events, were then obtained. 


\section{Results}

\subsection{Foliage phenology}

Of the 103 species with 4779 individuals observed, 54 species comprising 2933 individuals were evergreen and the rest (49 species; 1846 individuals) were deciduous. Leafing occurred twice in a year in Dalbergia latifolia and Pterocarpus marsupium and several times in Ficus infectoria. In the remaining deciduous species leaf production was seasonal (see appendices 1 and 2). In the palms Caryota urens and Arenga wightii leafing occurred throughout the year.

Emergence of young leaves peaked in Feb/Mar in all the study plots (figures 3, 4), and the maturation of leaves peaked in March. The abscission of leaves started in November, and lasted up to January with a peak in December. The emergence and
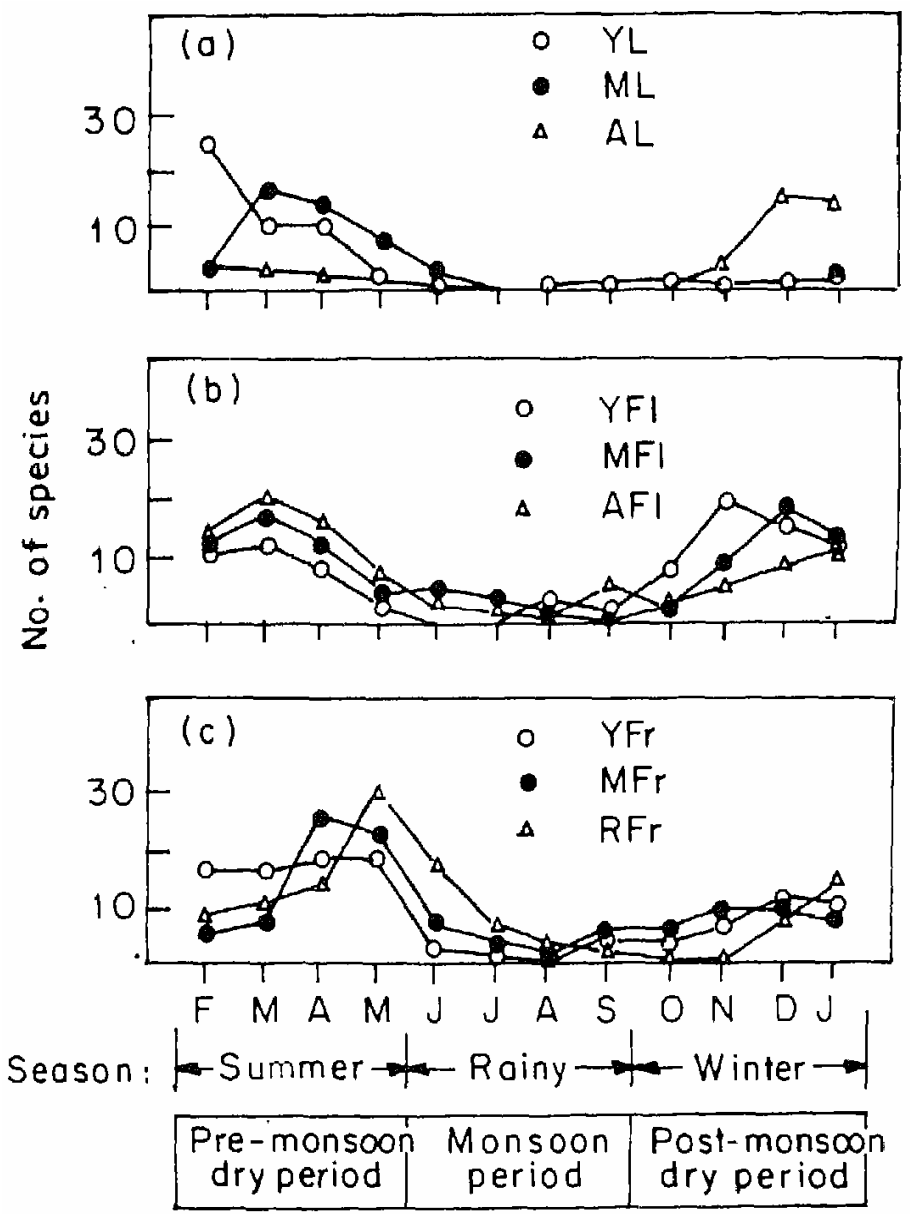

Figure 3. Seasonality in different phenological events in tropical moist forest of Uttara Kannada district.
(a) Leafing and leaf fall (b) Flowering (c) Fruiting.
L, Leaf; Fl, flower; Fr, fruit; Y, young; M, mature; R, ripe; A, abscission. 


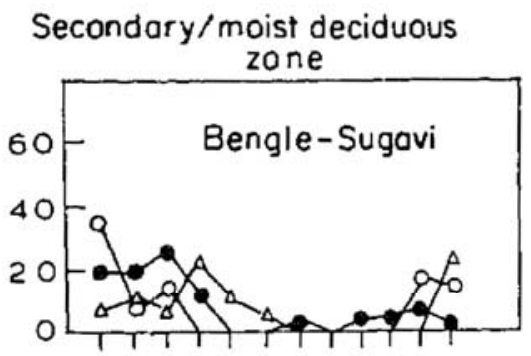

Evergreen/semi-evergreen
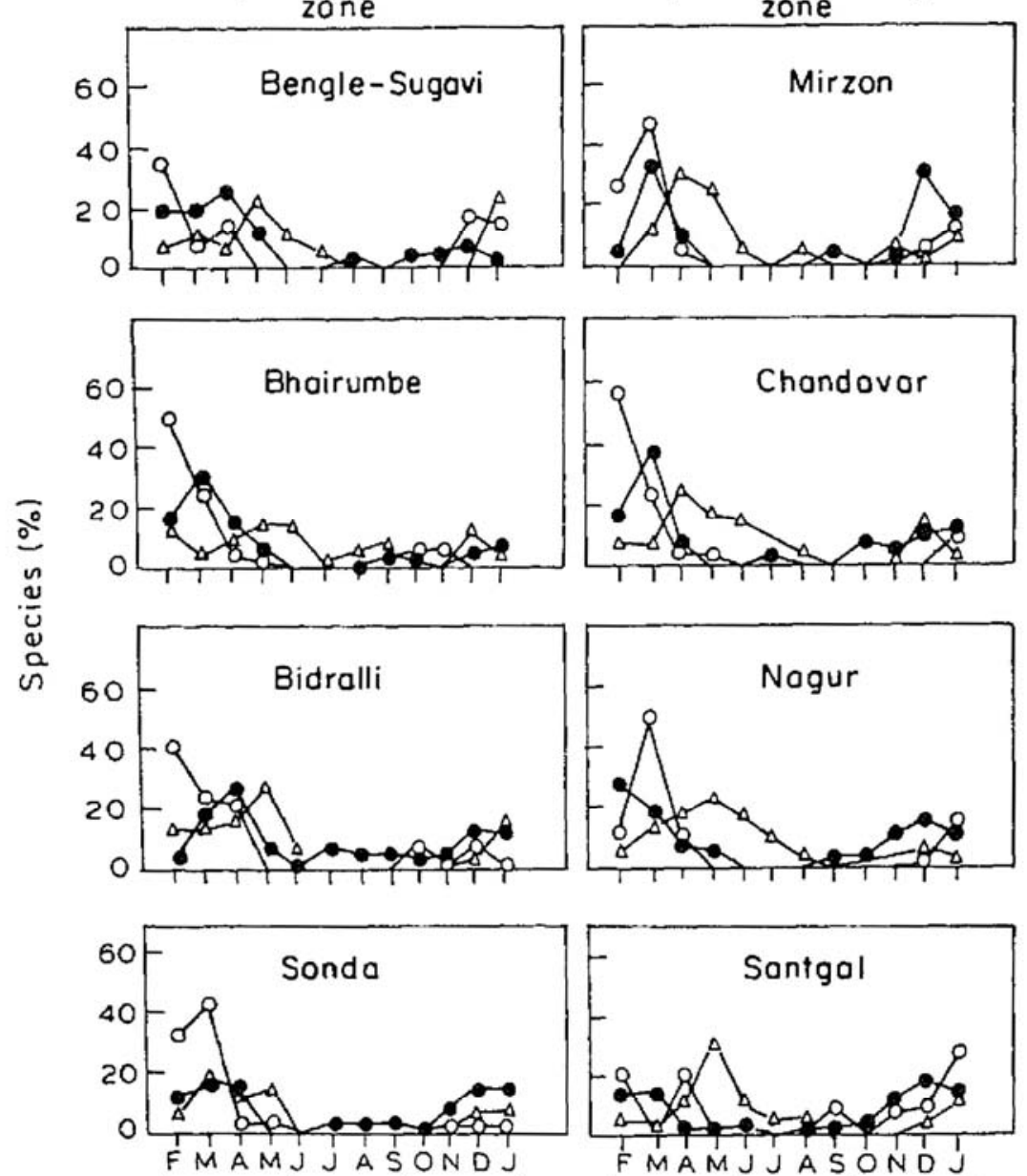

(a)
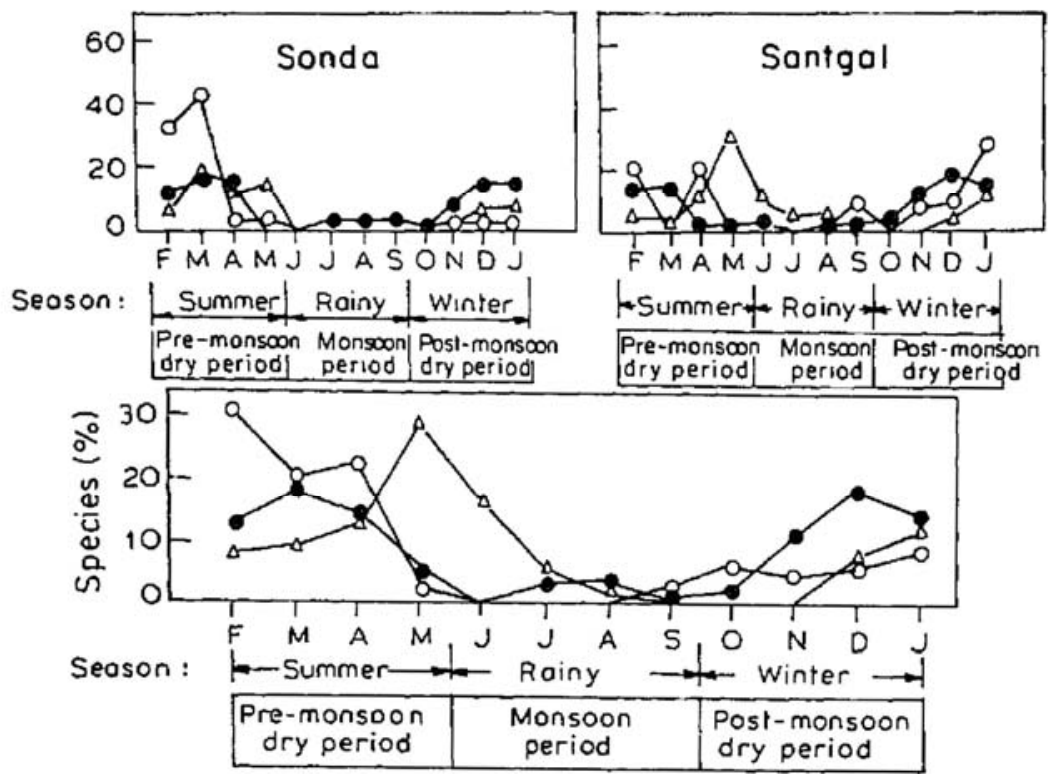

Figure 4. (a) Seasonality in major phenological events in the sites located in two different vegetation types in Uttara Kannada district. (b) Seasonality in major phenological events in the forest of Uttara Kannada district (pooled over all the eight sites).

(O), Emergence of leaves; ( ), flowering; $(\Delta)$, fruits. 
maturation of leaves coincided with longer day length and rise in temperature, while leaf abscission coincided with short day length and decrease in temperature (figures 3,4). The duration of leaf maturation varied from about 2 weeks in Wrightia tomentosa to 6 weeks in Ficus arnottiana. The period between maturation and abscission of leaves ranged from 185 days in Sapium insigne to 362 days in Mitragyna parviflora (appendix 1, see also figure 5). Many species remained leafless for quite a long period (see appendix 2), while Artocarpus lakoocha and Chukrassia tabularis retained the aged leaves till the newly emerged ones attained the full size.
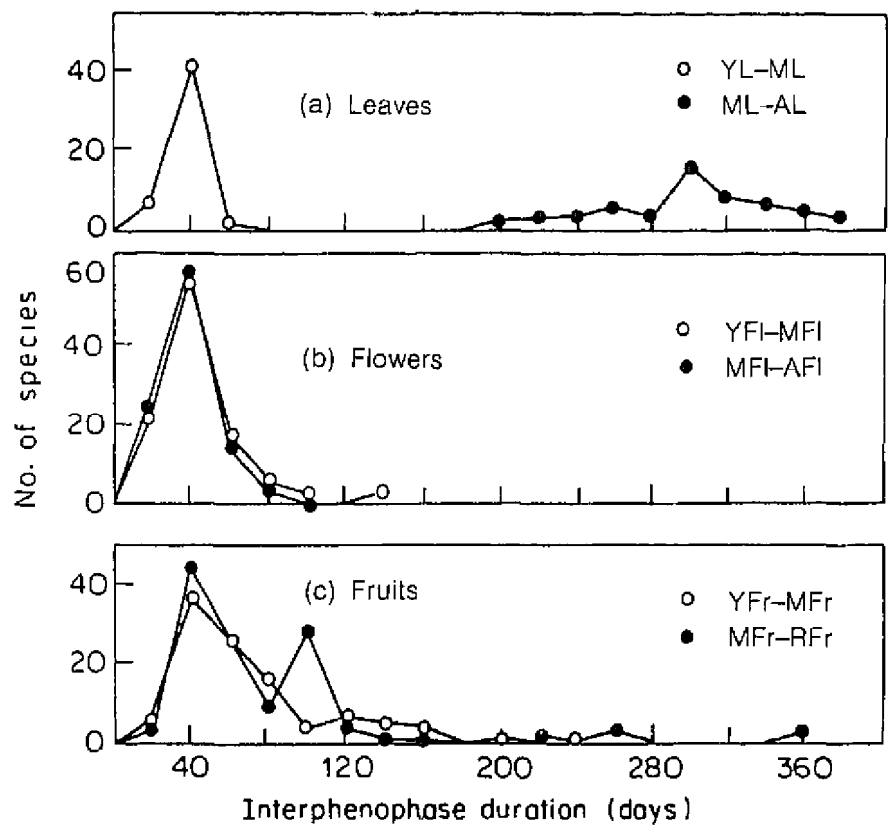

Figure 5. Spread of phenological events in tropical moist forest of Uttara Kannada district. Abbreviations as in figure 3.

\subsection{Reproductive phenology}

Flowering was continuous in the palm $C$. urens while it occurred twice in a year in $D$. latifolia and $P$. marsupium, and more than twice in $F$. infectoria. In the remaining species production of flower buds and anthesis were seasonal with two peaks; the larger peak was in March and smaller peak in December for anthesis (figures 3, 4). In all the study plots inspite of differences in vegetation types and in elevations, larger peak for flowering preceded the monsoon rainfall (figure 4). Similar pattern was observed in canopy trees and understorey trees (figure 6, also see appendix 2). In many species the period of flower abscission was short, and the duration between flower bud stage and anthesis ranged from less than 1 to 18 weeks (figure 5). On average, mature flowers of evergreen species lasted for a longer period than those of deciduous species (figure 7).

Fruit setting closely followed the abscission of flowers and the ripening of fruits occurred before the advent of monsoon rainfall, peaking in May-June (figures 3, 4). 


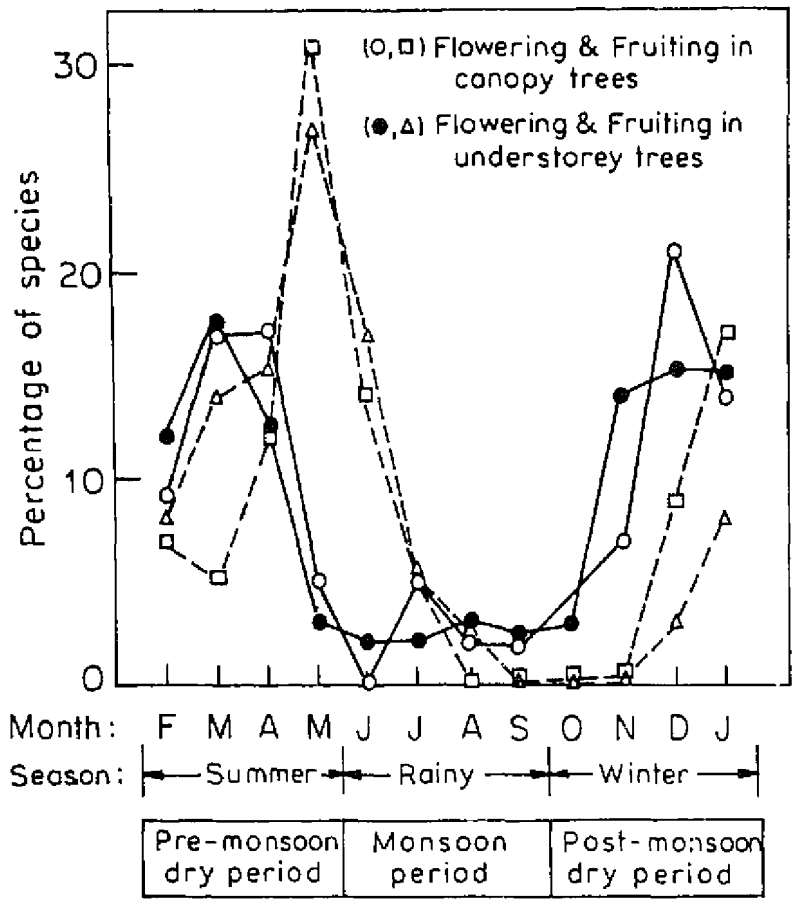

Figure 6. Seasonality in flowering and fruiting in canopy trees and understorey trees in the tropical moist forest of Uttara Kannada district.

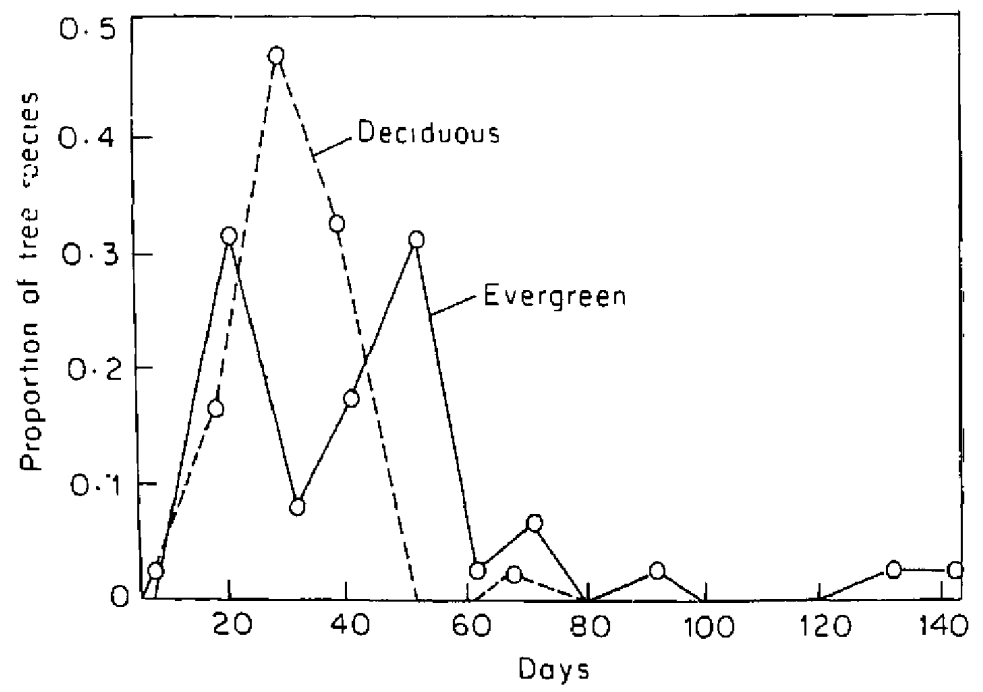

Figure 7. Length of phenophase of mature flowers in evergreen and deciduous species of tropical moist forest of Uttara Kannada district.

No significant shift was observed for peak fruiting between the plots, vegetation types, and among canopy and understorey tree species (figures 4, 6). Few species retained their fruits during the monsoon period and the post-monsoon dry period. 
The period between fruit setting and maturation ranged from 3 to 38 weeks and the mature fruits took 2 to 50 weeks to ripen (figure 5). On average, the phenophase of fleshy ripe fruits was shorter than that of dry fruits (figure 8), and the phenophase of ripe fruits in evergreen species was shorter than that in deciduous species (figure 9).

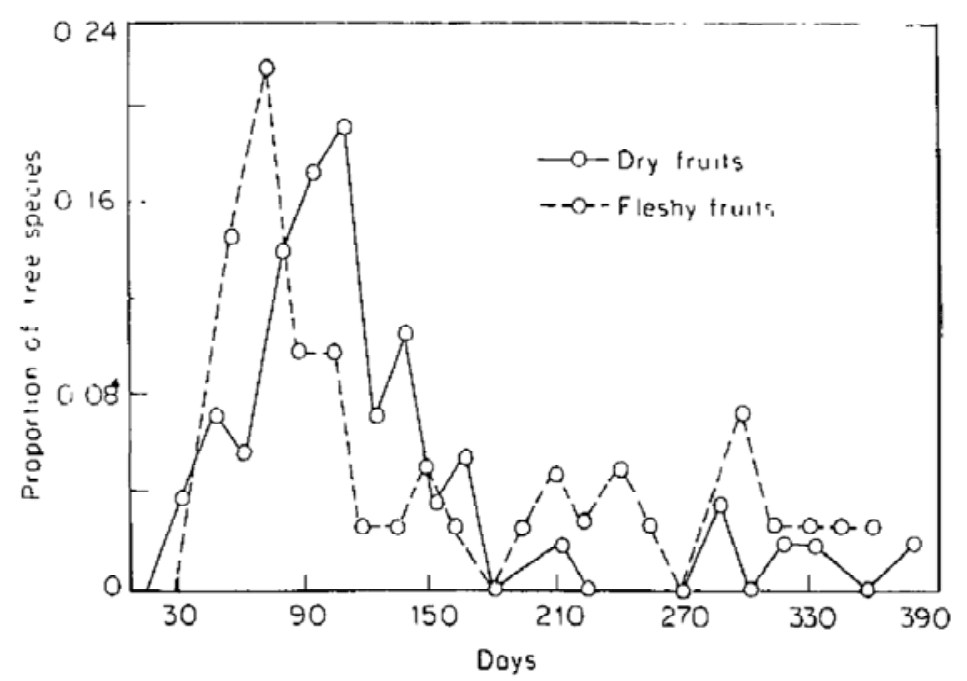

Figure 8. Length of phenophase of ripe fruits in species bearing dry and fleshy fruits in tropical moist forest of Uttara Kannada district.

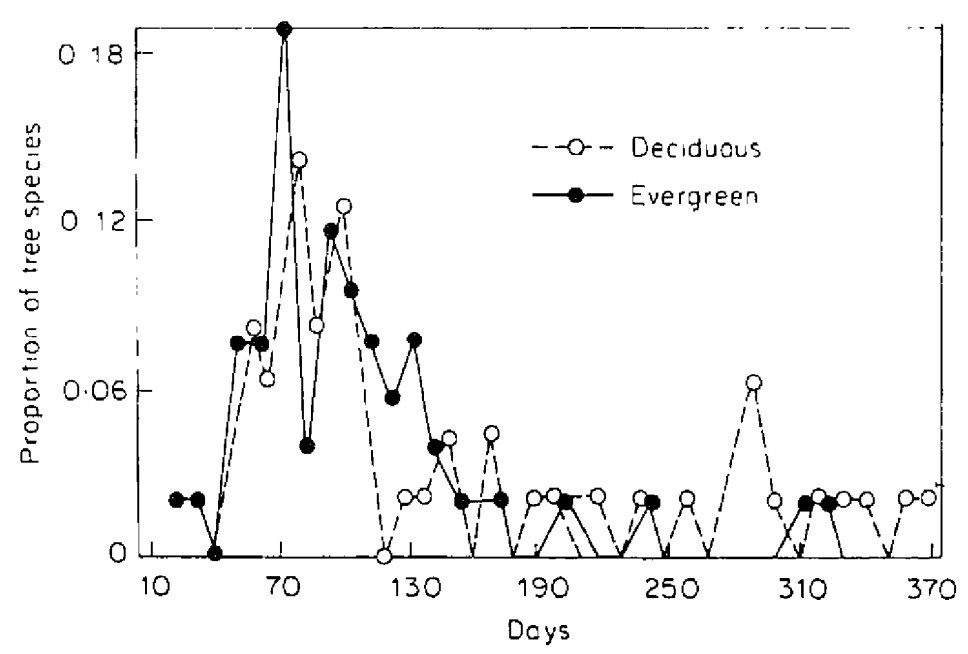

Figure 9. Length of phenophase of ripe fruits (includes dry and fleshy fruits) in evergreen and deciduous species in tropical moist forest of Uttara Kannada district.

\subsection{Ranges of interphenophase durations}

Interphenophase durations between different phenological events varied greatly for the evergreen and deciduous species in the community (table 2). The shortest range 
Table 2. Ranges of interphenophase durations between phenological events.

\begin{tabular}{|c|c|c|c|}
\hline & In community & In evergreen species & In deciduous species \\
\hline $\begin{array}{l}\text { Young leaves to maturation } \\
\text { of leaves (days) }\end{array}$ & $2 y$ & & 29 \\
\hline $\begin{array}{l}\text { Mature Mowers to } \\
\text { abscission of flowers (days) }\end{array}$ & 57 & 53 & 43 \\
\hline $\begin{array}{l}\text { Young flowers to maturation } \\
\text { of flowers (days) }\end{array}$ & 127 & 119 & 31 \\
\hline $\begin{array}{l}\text { Maturation of leaves to } \\
\text { abscission of leaves (days) }\end{array}$ & 177 & - & 177 \\
\hline $\begin{array}{l}\text { Young fruits to } \\
\text { maturation of fruits (days) }\end{array}$ & 254 & 254 & 250 \\
\hline $\begin{array}{l}\text { Maturation of fruits to } \\
\text { ripening of fruits (days) }\end{array}$ & 344 & 236 & 327 \\
\hline
\end{tabular}

was for maturation of leaves and the longest for fruiting. Retention of flowers in evergreen species was for a longer period than that in deciduous species.

\section{Discussion}

Recent studies have shown that seasonal peaks and depressions for leaf flush and leaf fall are quite common in tropical rainforests with pronounced dry period (Kramer and Kozlowski 1960; Fogden 1972; Kladik 1978). In tropics emergence of leaves peaked either in dry season (Frankie et al 1974b; Whitmore 1984) or in the wet season (Fogden 1972; Proctor et al 1983). For tropical plants leaf flush is attributed to onset of rain after a spell of dry period (Leigh and Windsor 1982; Prasad and Hegde 1986), water stress (Alvim 1964; Alvim and Alvim 1978), photoperiod (Daubenmire 1972) and temperature (Schaik 1986). In many tropical sites first peak of leaf emergence was in the first dry season of the year when the temperature reached maximum (see table 3). In tropical moist forest of Uttara Kannada leaf flush occurred in the early part of pre-monsoon dry period during which the rainfall was minimum. Inspite of low soil moisture, deciduous species in

Table 3. Comparison of climate and phenological features in a range of tropical forest sites.

\begin{tabular}{|c|c|c|c|c|c|c|}
\hline & $\begin{array}{l}\text { Ulu Gombak, } \\
\text { W. Malaysia } \\
\text { (Medway } \\
\text { 1972) }\end{array}$ & $\begin{array}{l}\text { Bandipur, } \\
\text { India } \\
\text { (Prasad and } \\
\text { Hegde } \\
1986 \text { ) }\end{array}$ & $\begin{array}{l}\text { Ketambe, } \\
\text { Sumatra } \\
\text { (Schaik } \\
\text { 1986) }\end{array}$ & $\begin{array}{l}\text { Chamela, } \\
\text { Mexico } \\
\text { (Bullock and } \\
\text { Solis- } \\
\text { Magallanes } \\
\text { 1990) }\end{array}$ & $\begin{array}{l}\text { La Selva, } \\
\text { Costa Rica } \\
\text { (Frankıe } \\
\text { et al. } \\
1974 \text { ) }\end{array}$ & $\begin{array}{l}\text { Uttara Kannadia } \\
\text { India } \\
\text { (This study) }\end{array}$ \\
\hline Rainfal|* & $\mathrm{B}$ & $\mathrm{U}$ & $\mathrm{B}$ & $\mathrm{U}$ & $\mathrm{B}$ & $\mathbf{U}$ \\
\hline $\begin{array}{l}\text { First peak of leaf } \\
\text { emergence }\end{array}$ & Mar-May & Apr-May & Dec-Feb & Jun-Ju! & Feb & Feb \\
\hline $\begin{array}{l}\text { Second peak of leaf } \\
\text { emergence }\end{array}$ & ca. Dec & Jul-Sep & Aug & - & Sep & - \\
\hline Peak of leaf fall & - & Dect-Jan & Jan & & Feb & Dec \\
\hline First peak of flowering & Mär-Jul & Apr-May & Feb-Apr & Jun-Jul & May & Mar \\
\hline Second peak of flowering & - & - & - & Oct & - & Dec \\
\hline First peak of fruiting & Aug-Sep & Nov-Dec & Jul-Aug & Nov-Dec & Sep & May-Jun \\
\hline Second peak of fruiting & - & - & - & Aug & - & $\cdots$ \\
\hline Month of maximum temperature & Mar & - & Mar & - & May & Apr \\
\hline Period of maximum rainfall & Oct-Dec & Jun-Sep & Sep-Nov & Jul-Oct & Jun-Oct & Jun-Sep \\
\hline
\end{tabular}

*B. Bimodal rainfall; U. unimodal rainfall. 
all the study locations produced new leaves during early part of summer season (figures 3, 4). The reasons for emergence and maturation of leaves in the premonsoon period could be that this dry period is short, temperature is at its maximum and day length increases. These environmental factors have been accepted to be favourable for maximizing photosynthesis and vegetative growth (Sharma 1970; Salisbury and Ross 1974). On the other hand, leaf fall coincided with short day length and decrease in temperature; however, leaf abscission occurred over a wider span of time than did leaf emergence. The species specific leaf shedding phenology affecting the shift in peak leaf fall has been discussed elsewhere (KunkelWestphal and Kunkel 1979; Songwe et al 1988; Bhat 1990).

In all the eight forest localities of Uttara Kannada district, the larger flowering peaks occurred in March/April (figure 4). In other tropical sites also flowering peaked close to the month of highest temperature (see table 3) and increasing day length. Very often synchronous flowering is correlated with rainfall after dry spell (Augspurger 1982) and such flowering is believed to attract pollinators (Bullock and Bawa 1981) as insect activity is probably greatest in the months with warm and dry days (Janzen 1967; Kaul et al 1986; Schaik 1986). However, two distinct peaks were observed for emergence of flower buds and anthesis when species were classified with respect to their leaf shedding nature. Deciduous species tended to flower in premonsoon dry period while many of the evergreen species flowered in the later part of the winter period (figure 10). Flowering in different seasons may be to avoid competition for pollinators. Unlike species that flower during the later part of the winter season, which do not experience heavy demands for energy for vegetative growth, species that bloom during the pre-monsoon dry period make large investment in reproduction while leafless or flushing and must depend on reserve food (Bullock and Solis-Magallanes 1990). Advantage of dry-season flowering is that it makes flowers more visible to pollinators since the trees lack leaves (Janzen

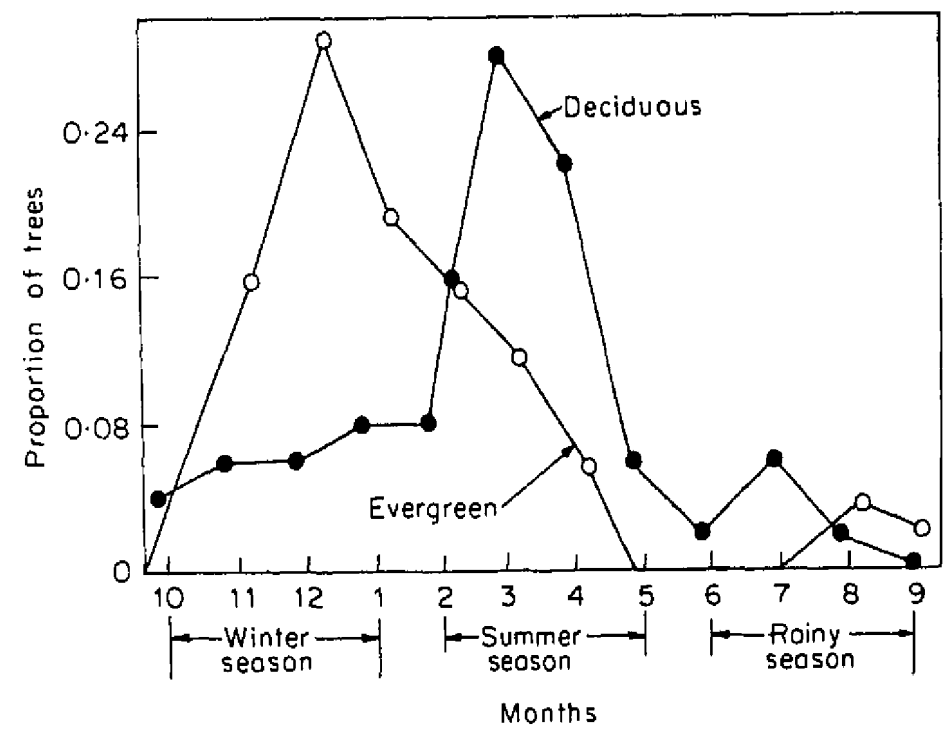

Figure 10. Proportions of evergreen and deciduous species in peak flower in different seasons in tropical moist forest of Uttara Kannada district. 
1967). A few species exhibit unusual phenological patterns. For instance, the palm C. urens starts reproduction after a long period of growth and continues to produce inflorescences until its last leaf comes out as inflorescence and later the palm dies. Such a pattern of reproduction could be to maximize output of seeds, In Mappia foetida, which is an understorey tree, flowering occurs in late rainy season. The odd season flowering is accompanied by strong odour of the flowers.

In majority of species fruits ripen close to monsoon rainfall, As shown in table 3, the fruiting peak in the forest of Uttara Kannada district was similar to that in other tropical sites (i.e. ripening of fruits in the later part of premonsoon dry period or close to rainfall). Similar feature observed earlier has been explained to gain post dispersal success (Rathcke and Lacey 1985), escape predation (Janzen 1983), enhance disersal (Foster 1982a; Prasad and Sharatchandra 1984) and avoid pathogen infection (Augspurger 1983). In a few species such as Lagerstroemia microcarpa, C. tabularis and Terminalia paniculate fruits ripen at odd seasons (post rainy season) when the germination success is usually minimal and incidence of pest and pathogen attack is high. Ripening of fruits in pre-monsoon dry period, especially in species dispersed by wind, could be a consequence of selection to disperse propagules at a time when the wind velocity is maximum. Odd season ripening of fruits in some of the hard seed-coated species such as Terminalia bellerica, T. chebula, Phyllanthus emblica may help in. dispersal since many are ingested by wildlife and voided elsewhere. $F$. infectoria produced fruits several times in a year. Many studies of fruit phenology of tropical rainforests have indicated that figs fruit asynchronously at the poulation level (Janzen 1979; Lighton and Leighton 1983), and it has been suggested that this trait may lower intraspecific competition for dispersal services and thus maximize dispersal success (Milton et al 1983).

Of the ranges observed for six phenophases the shortest was for maturation of leaves and the longest was for ripening of fruits. Longer duration of fruiting implies the availability of fruits and seeds to frugivores and seed predators for a longer period of time. This could be one of the reasons for predominance of frugivorous birds in the Santgal forest which is in evergreen/semievergreen forest zone of the district (Daniels et al 1990). Though the flowering is in two peaks the ripening of fruits is concurrent, resulting in a single peak close to monsoon rainfall. Concurrent ripening of fruits is effected in evergreen species by extending the flowering episode and shortening the fruiting duration.

\section{Conclusion}

A strong seasonality exists with respect to vegetative and reproductive phenology in tree species of tropical moist forest of Uttara Kannada district. Increasing day length and rise in temperature during the pre-monsoon dry period are probably responsible for leaf flush and maturation, while shorter day length and decrease in temperature may have induced leaf drop during the post-monsoon period. Flowering in two peaks is probably driven by change in temperature, and synchronized flowering in the early part of the pre-monsoon dry period may attract the pollinators. Concurrent ripening of fruits by majority of species in pre-monsoon period may offer post dispersal advantage for seeds to germinate. Avoiding 
herbivore damage and maximum photosynthesis under favourable environmental condition are achieved by short interphenophase duration of leaf maturation.

\section{Acknowledgements}

The author is grateful to $\mathrm{Dr} \mathrm{S}$ Narendra Prasad for creating interest for phenological studies and to Prof. Madhav Gadgil for his valuable guidance and encouragement during the study. This work was supported by grants from the Ministry of Environment and Forests, Government of India.

Appendix 1. List of species, number of individuals, interphenophase durations and leaf shedding nature for tree species of tropical moist forest of Uttara Kannada district.

\begin{tabular}{|c|c|c|c|c|c|c|c|c|c|}
\hline \multirow[b]{2}{*}{ Species } & \multirow{2}{*}{$\begin{array}{l}\text { Canopy/ } \\
\text { under- } \\
\text { storey } \\
\text { tree }\end{array}$} & \multirow[b]{2}{*}{$\begin{array}{c}\text { No. of } \\
\text { indivi- } \\
\text { duals }\end{array}$} & \multicolumn{6}{|c|}{ Interphenophase duration (in days) } & \multirow[b]{2}{*}{$\begin{array}{c}\text { Leal } \\
\text { shedding } \\
\text { r nature }\end{array}$} \\
\hline & & & YL-ML & ML-AL & F $1-M F 1$ & MF1-AF1 & YFr-MFt & $\mathrm{MFr}-\mathrm{RFr}$ & \\
\hline \multicolumn{10}{|l|}{1 Anacardiaceac } \\
\hline 1. Buchananian lanzan & unt. & 31 & 33 & 279 & 26 & 24 & 31 & 28 & D \\
\hline 2. Holigarma arnottiana & unt. & 164 & - & - & 48 & 34 & 85 & 51 & $E$ \\
\hline 3. H. grahamif & cant. & 3 & - & - & 46 & 20 & $\$ 4$ & 39 & $\mathrm{E}$ \\
\hline 4. Mangifera indica & cant. & 15 & - & 一 & 41 & 35 & 44 & 61 & $\mathrm{E}$ \\
\hline 5. Nothopegia colebrookeana & unt. & 205 & - & - & 18 & 28 & 27 & 33 & $E$ \\
\hline 6. Odina woodier & unt. & 37 & 25 & 283 & 28 & 28 & 59 & 40 & $D$ \\
\hline 7. Spondias accuminata & unt. & 1 & 30 & 304 & 30 & 28 & 37 & 248 & D \\
\hline \multicolumn{10}{|l|}{ II Annonaceae } \\
\hline 8. Bocagia dalzellii & unt. & 1 & - & - & 19 & 32 & 27 & 51 & $\mathrm{E}$ \\
\hline 9. Polyalthia fragrans & cant. & 14 & - & - & 16 & 22 & 79 & 45 & E \\
\hline \multicolumn{10}{|l|}{ II] Apocyanaceae } \\
\hline 10. Alstonia scholaris & cant. & 9 & - & - & 44 & 33 & 28 & 39 & $\mathrm{E}$ \\
\hline 11. Ervatamia heyneana & unt. & 139 & 39 & 323 & 28 & 34 & 54 & 92 & D \\
\hline 12. Wrightia tomentosa & unt. & 25 & 16 & 288 & $\begin{array}{c}\text { less than } \\
\text { a week }\end{array}$ & & 35 & 31 & D \\
\hline \multicolumn{10}{|l|}{ IV Bignoniaceae } \\
\hline $\begin{array}{l}\text { 13. Heterophragma } \\
\text { dalzellii }\end{array}$ & unt. & 4 & 39 & 316 & 39 & 77 & 30 & 67 & D \\
\hline 14. Stereospermum sp. & cant. & 10 & 34 & 291 & 21 & 23 & 38 & 217 & $\mathrm{D}$ \\
\hline \multicolumn{10}{|l|}{ V Boraginaceae } \\
\hline 15. Ehretia sp. & unt. & 26 & - & $\cdots$ & 15 & 48 & 25 & 20 & $\mathrm{E}$ \\
\hline \multicolumn{10}{|l|}{ VI Combretaceae } \\
\hline 16. Terminalia alata & cant. & 144 & 25 & 273 & 32 & 31 & 142 & 144 & $\mathrm{D}$ \\
\hline 17. $T$. bellerica & cant. & 57 & 34 & 305 & 29 & 16 & 152 & 141 & $\mathrm{D}$ \\
\hline 18. $T$. chebula & unt. & 8 & 33 & 231 & 23 & 20 & 58 & 267 & D \\
\hline 19. T. paniculata & cant. & 323 & 29 & 295 & 38 & 33 & 42 & 105 & D \\
\hline \multicolumn{10}{|l|}{ VII Dilleniaceae } \\
\hline 20. Dillenia pentagyna & cant. & 56 & 25 & 328 & 31 & 28 & 35 & 36 & D \\
\hline \multicolumn{10}{|l|}{ VIII Dipterocarpaceae } \\
\hline 21. Hopea wightiana & cant. & 937 & - & - & 61 & 29 & 23 & 71 & E \\
\hline 22. Shorea talura & cant. & 3 & - & - & 50 & 59 & 30 & 23 & E \\
\hline
\end{tabular}


Appendix 1. (Continued)

\begin{tabular}{|c|c|c|c|c|c|c|c|c|c|}
\hline \multicolumn{10}{|l|}{ IX Ebenacease } \\
\hline 23. Diospyros cundoleana & unt. & 116 & - & - & 43 & 32 & 58 & 57 & E \\
\hline 24. D. melanoxylon & unt. & 4 & 21 & 344 & 34 & 18 & 21 & 344 & D \\
\hline 25. D. microphylla & cant. & 15 & - & - & 19 & 22 & 270 & 39 & $\mathrm{E}$ \\
\hline 26. D. momana & unt. & 29 & 19 & 294 & 22 & 23 & $59^{\circ}$ & 37 & $\mathbf{D}$ \\
\hline 27. D. pruriens & unt. & 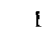 & - & - & 26 & 14 & 54 & 39 & $\mathbf{E}$ \\
\hline \multicolumn{10}{|l|}{$X$ Euphorbiaceac } \\
\hline 28. Aporosa lindleyana & unt. & 217 & - & - & 43 & 33 & 67 & 60 & $\mathrm{E}$ \\
\hline 29. Bischofia javanica & cant. & 29 & 26 & 319 & 26 & 52 & 30 & 64 & $\mathrm{D}$ \\
\hline 30. Macaranga tomentosa & cant. & 21 & - & - & 47 & 28 & 37 & 28 & $\mathbf{E}$ \\
\hline 31. Mallotus philippensis & unt. & 19 & - & - & 44 & 31 & 61 & 41 & $\mathbf{E}$ \\
\hline 32. Phyllanthus emblica & unt. & 31 & 35 & 284 & 30 & 25 & 120 & 84 & $\mathrm{D}$ \\
\hline 33. Sapium insigne & unt. & 12 & 31 & 185 & 20 & 22 & 45 & 90 & $\mathrm{D}$ \\
\hline
\end{tabular}

XI Bixaccaceae

108

XII Gutiferae

35. Calophylum inophyllum cant.

36. Garcinia indica unt

37. Ocirrocarpus longifolius cant.

$\begin{array}{llll}1 & - & - & 15 \\ 8 & - & - & 35\end{array}$

XIII Lauraceae

\begin{tabular}{|c|c|c|c|c|c|c|c|c|c|}
\hline 38. Actinodaphne hookeri & unt. & 10 & $\ldots$ & - & 33 & 15 & 141 & 58 & $\mathrm{E}$ \\
\hline $\begin{array}{l}\text { 39. Alseodaphne } \\
\text { semicarpifolia }\end{array}$ & cant. & 36 & - & - & 39 & 26 & 36 & 32 & $\mathbf{E}$ \\
\hline 40. Cinnamonium sp. & cant. & 30 & - & - & 43 & 22 & 35 & 44 & $E$ \\
\hline 41. Machilus macarantha & cant. & 15 & - & - & 20 & 15 & 74 & 42 & $\mathrm{E}$ \\
\hline
\end{tabular}

XIV Leguminosae

$\begin{array}{llrlllllll}\text { 42. Albizzia odoratissima } & \text { cant. } & 3 & - & -3 & 26 & 18 & 199 & 41 & \text { E } \\ \text { 43. Butea frondosa } & \text { unt. } & 2 & 30 & 294 & 23 & 21 & 30 & 79 & \text { D } \\ \text { 44. Cassia fistula } & \text { unt. } & 16 & 27 & 258 & 28 & 23 & 136 & 124 & \text { D } \\ \text { 45. Daibergia latifolia } & \text { unt. } & 9 & 30 & 258 & 19 & 21 & 37 & 40 & \text { D + } \\ \text { 46. D. paniculata } & \text { cant. } & 1 & 18 & 307 & 18 & 15 & 128 & 34 & \text { D } \\ \text { 47. Pterocarpus marsupium } & \text { cant. } & 6 & 25 & 210 & 30 & 17 & 59 & 26 & \text { D + } \\ \text { 48. Xylia xylocarpa } & \text { unt. } & 240 & 31 & 317 & 32 & 27 & 270 & 64 & \text { D }\end{array}$

XV Longaniaceae

49. Strychnos nuxvomica cant

XVI Lythraceae

50. Lagerstroemia microcarpa

cant.

37

XVII Malvaceae

51. Bombax malabarica

52. Kydia calycino

cant.

unt.

236

259

284

$19 \quad 26 \quad 26$

43

D

XVIII Melastomaceae

53. Memecylon sp.

unt.

22
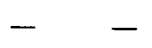

38

cant.

54. Aglaia sp.

55. Chukrassia tabularis

$25 \quad-\quad-$

S6. Dysoxylum binectarifertum

57. D. malabaricum

cant.

$4 \quad 40 \quad 329$

18

33

$19-$

57

unt.

$42 \quad-\quad$

19

$12 \quad 20$

D

E

E 
Appendix 1. (Continued)

XX Myrsticaceae

58. Myrstica attenuata

59. Myristica malabarica

unt.

$52 \quad-\quad-$

$\begin{array}{lll}39 & 27 & 93\end{array}$

$30 \quad E$

XXI Myrtaceae

60. Careya arborea

unt.

1

27

113

41

$E$
$E$

61. Eugenia corymbosa

62. E. jambolana

63. Eugenia sp.

unt. $\quad 72 . \quad 24$

$\begin{array}{lrrrr}\text { unt. } & 1 & - & - & 41 \\ \text { cant. } & 12 & - & - & 125\end{array}$

cant. $12 \div 125$

unt.

2

XXII Olacaceae

64. Mappia foetida

65. Strombosia ceylanica

unt.

$\begin{array}{llll}\text { unt. } & 23 & 18 & 28\end{array}$

39

$26 \quad 36$

$17 \quad 52$

$25 \quad 29$

$21 \quad 26$

30

37

D

XXIII Oleaceae

66. Linociera

malabaricum

67. Olea dioica

$\begin{array}{llll}19 & - & - & 48 \\ 200 & - & - & 21\end{array}$

$48 \quad 20$

unt.

21

95

35

$31 \mathrm{E}$

XXIV Palmae

68. Arenga wightit

69. Caryota urens +

unt.

$1 \quad-$

$18 \quad 46$

29

117

E

XXV Rhamnaceae

70. Zizyphus xylopyra

unt.

$12 \quad 37$

281

All seasons

E

XXVI Rhizophoracese

71. Carallia integerrima

cant.

3

$\begin{array}{lrllllrll}\text { cant. } & 31 & 31 & 230 & 38 & 26 & 100 & 8 \overline{8} & \bar{D} \\ \text { unt. } & 188 & - & - & 66 & 19 & 50 & 32 & \text { E } \\ \text { cant. } & 3 & 30 & 362 & 37 & 38 & 135 & 85 & \text { D } \\ \text { unt. } & 4 & - & - & 66 & 13 & 67 & 49 & \text { E } \\ \text { unt. } & 170 & 30 & 290 & 32 & 28 & 224 & 90 & \text { D } \\ \text { unt. } & 54 & 33 & 279 & 34 & 41 & 40 & 42 & \text { D }\end{array}$

XXVII Rubiaceae

72. Adina cordifolia

73. Ixora brachiata

74. Mitragyna parviflora

75. Plectronia wigheif

76. Randia dumetorum

77. R. uliginosa

unt.

unt.

unt.

$14 \quad 16$

206

78. Murraya exotica

79. Zanthoxylum rhetsa

unt. 23

44

unt.

$\begin{array}{rrr}9 & - & -\end{array}$

15
84

29

72

92 D

XXIX Samydaceae

80. Casearia sp.

81. Nephelium longana

cant.

7

XXX Sapindaceae

82. Sapindus laurifolius

83. Schleichera trijuga

unt.

unt.

$\begin{array}{rrr}3 & 25 & 285 \\ 12 & 28 & 298\end{array}$

$29 \quad 41 \quad 51$

$\begin{array}{lll}29 & 41 & 51 \\ 35 & 23 & 31\end{array}$

40
48

$\mathrm{D}$

XXXI Sapotaceae

84, Bassia lutifolio

85. B. malabarica

$12 \quad 36 \quad 288$

86. Mimusops eleng

87. Sideroxylon tomentosa

unt.

cant.

XXXII Simarubiaceae

88. Ailanthus malabaricum cant.

XXXIII Sterculiaceae

89. Prerospermum acerifolium

cant.

71

$\begin{array}{rrrr}12 & - & - & 18 \\ 15 & - & - & 24\end{array}$

49

24
20
43
46

21

103

$66 \quad 41$

E

E

E 
Appendix 1. (Continued)

\begin{tabular}{|c|c|c|c|c|c|c|c|c|c|}
\hline 90. P. heyнeanum & cant. & 22 & - & - & 18 & 46 & 79 & 45 & E \\
\hline 91. Sterculia sp. & unt. & 13 & 28 & 327 & 25 & 31 & 32 & 28 & $\mathrm{D}$ \\
\hline \multicolumn{10}{|l|}{ XXXIV Styraceae } \\
\hline 92. Symploc'os sp. & unt. & 14 & - & - & 15 & 16 & 46 & 23 & $\mathbf{E}$ \\
\hline \multicolumn{10}{|l|}{ XXXV Tiliaceae } \\
\hline 93. Elacocarpus serrasus & cant. & 8 & - & - & 37 & 34 & 43 & 46 & $\mathbf{E}$ \\
\hline 94. Grewia tiliaefolia & unt. & 11 & 38 & 282 & 36 & 29 & 41 & 33 & $\mathrm{D}$ \\
\hline \multicolumn{10}{|l|}{ XXXVI Urticaceae } \\
\hline 95. Artocarpus hirsuta & cant. & 1 & 25 & 340 & 30 & 31 & 62 & 24 & $D$ \\
\hline 96. A. lakoocha & unt. & 3 & 22 & 345 & 20 & 25 & 50 & 53 & $\mathrm{D}$ \\
\hline 97. Ficus arnottiana & unt. & 7 & 45 & 257 & 31 & 17 & 43 & 44 & $\mathrm{D}$ \\
\hline 98. $F$. asperrima & unt. & 13 & 27 & 249 & 34 & 28 & 20 & 52 & $\mathrm{D}$ \\
\hline 99. $F$. callosa & cant. & 8 & - & - & 32 & 21 & 47 & 58 & $E$ \\
\hline 100. $F$, nervosa & cant. & 1 & - & - & 16 & 27 & 16 & 42 & E \\
\hline 101. F. infectoria & cant. & 4 & - & - & Several & times & & & $D+$ \\
\hline \multicolumn{10}{|l|}{ XXXVII Verbeneceac } \\
\hline 102. Gmelina arborea & unt. & 1 & 18 & 304 & 30 & 34 & 78 & 17 & $D$ \\
\hline 103. Vitex altissima & unt. & 49 & 28 & 332 & 29 & 31 & 64 & 66 & $\mathrm{D}$ \\
\hline Total evergreen individuals: & 2933 & \multicolumn{8}{|c|}{ Total evergreen species: 54} \\
\hline Total deciduous individuals: & 1846 & \multicolumn{8}{|c|}{ Total deciduous species: 49} \\
\hline & 4779 & \multicolumn{8}{|c|}{103} \\
\hline
\end{tabular}

Cant., Canopy tree; unt., understorey tree.

D, Deciduous species; E, evergreen species.

L, leaf; Fl, flower; Fr, fruit; Y, young; M, mature; A, abscission; R, ripe.

+ , Leafing, flowering and fruiting in all seasons; ++ , leafing, flowering and fruiting twice in a year; +++ , leafing, flowering and fruiting several times in a year.

Family and nomenclature follows Cooke (1967). 


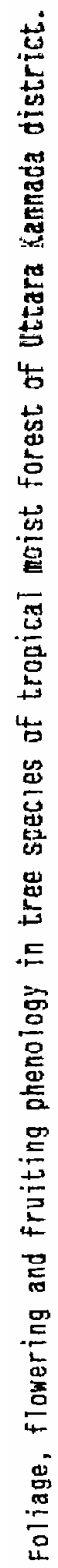

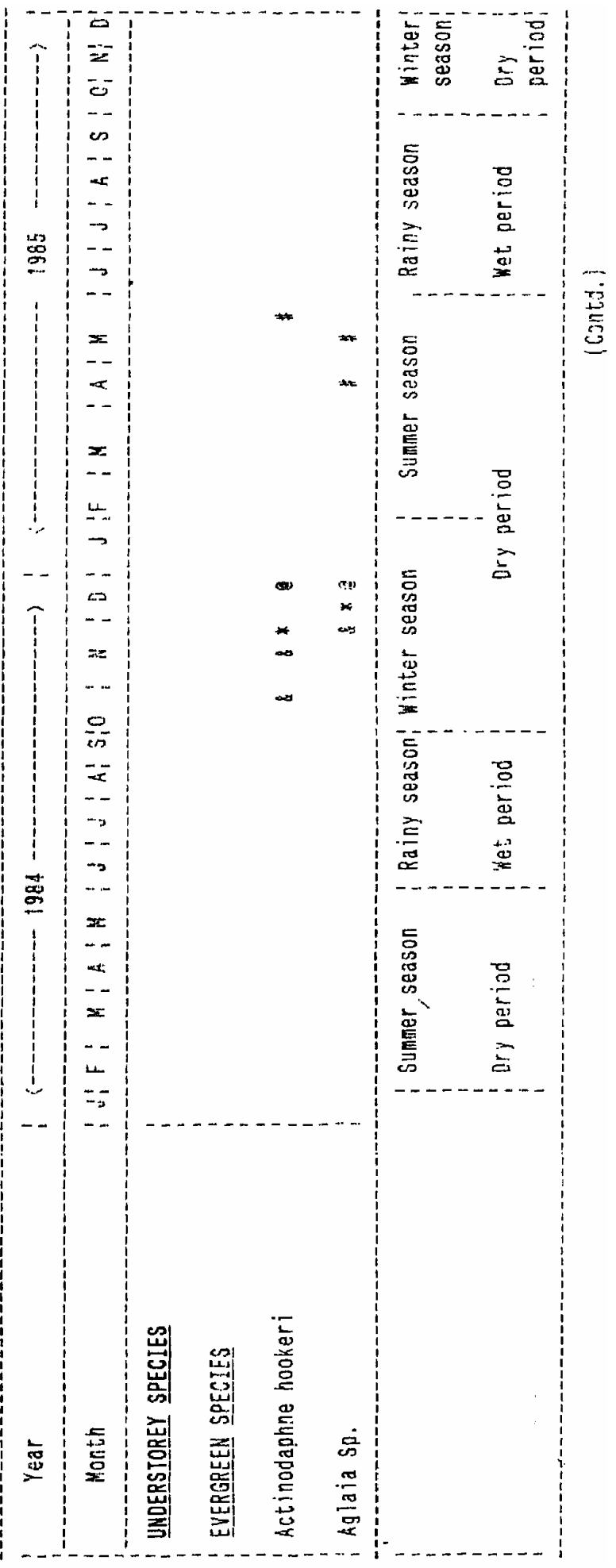




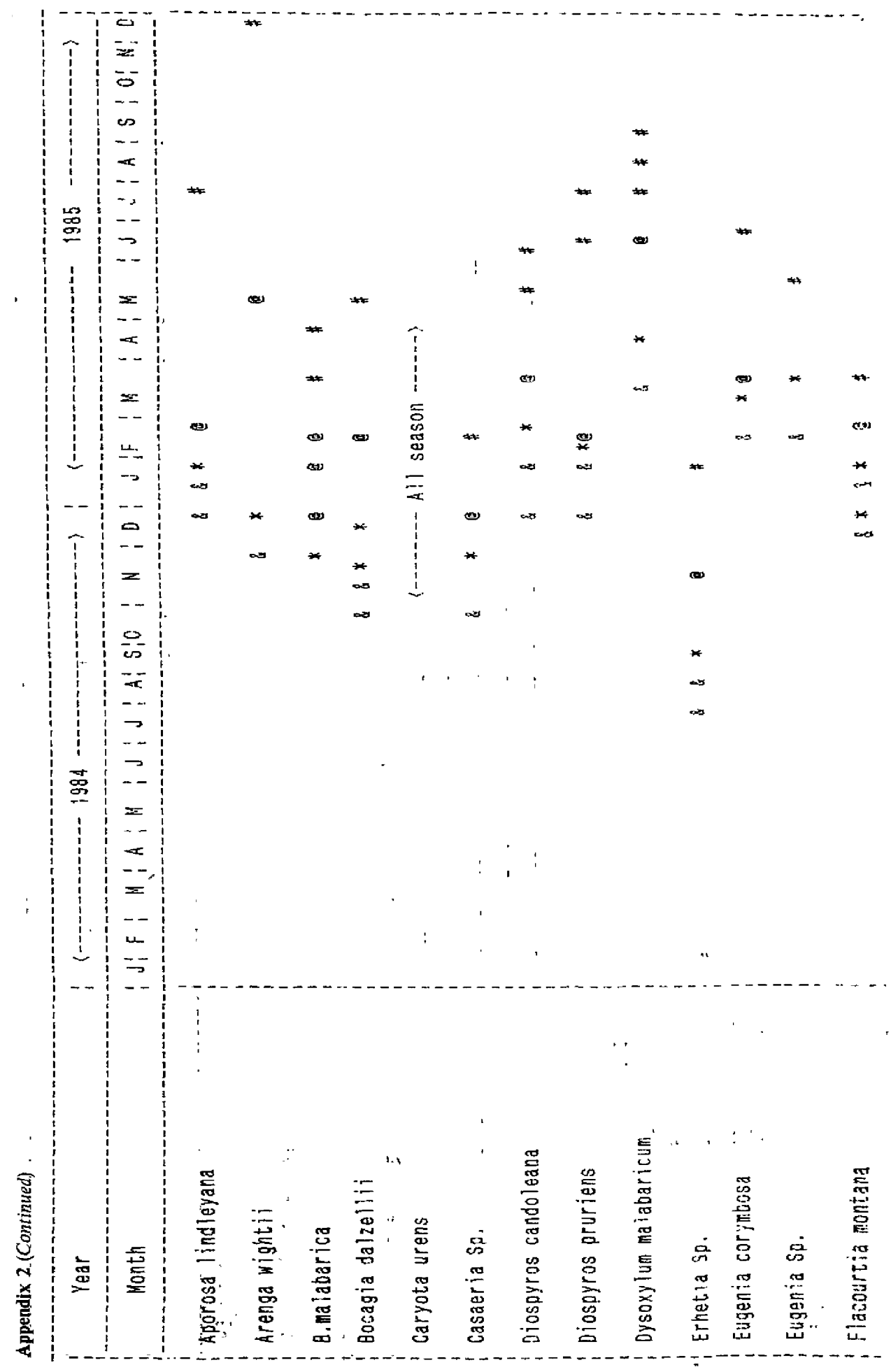




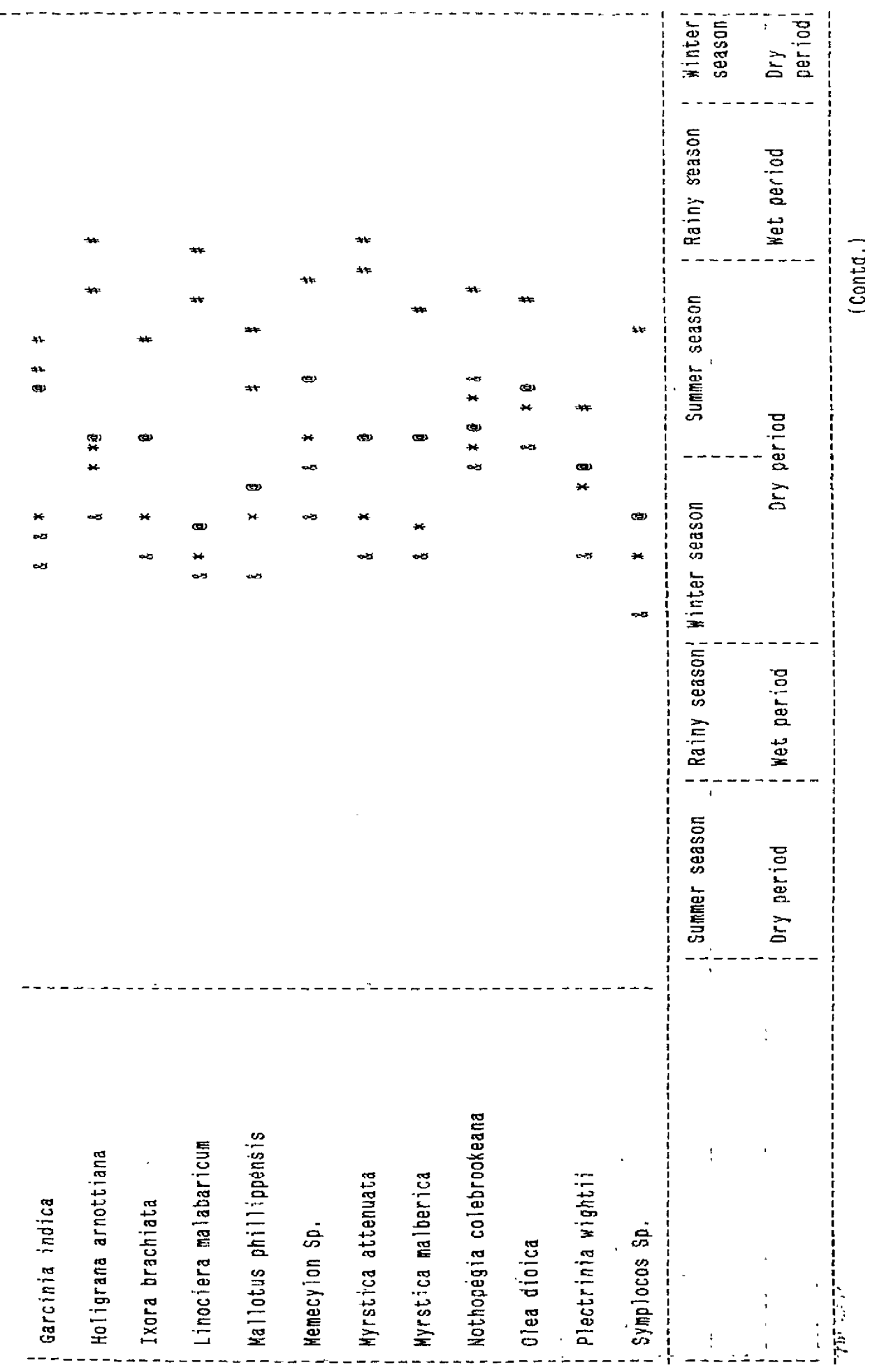




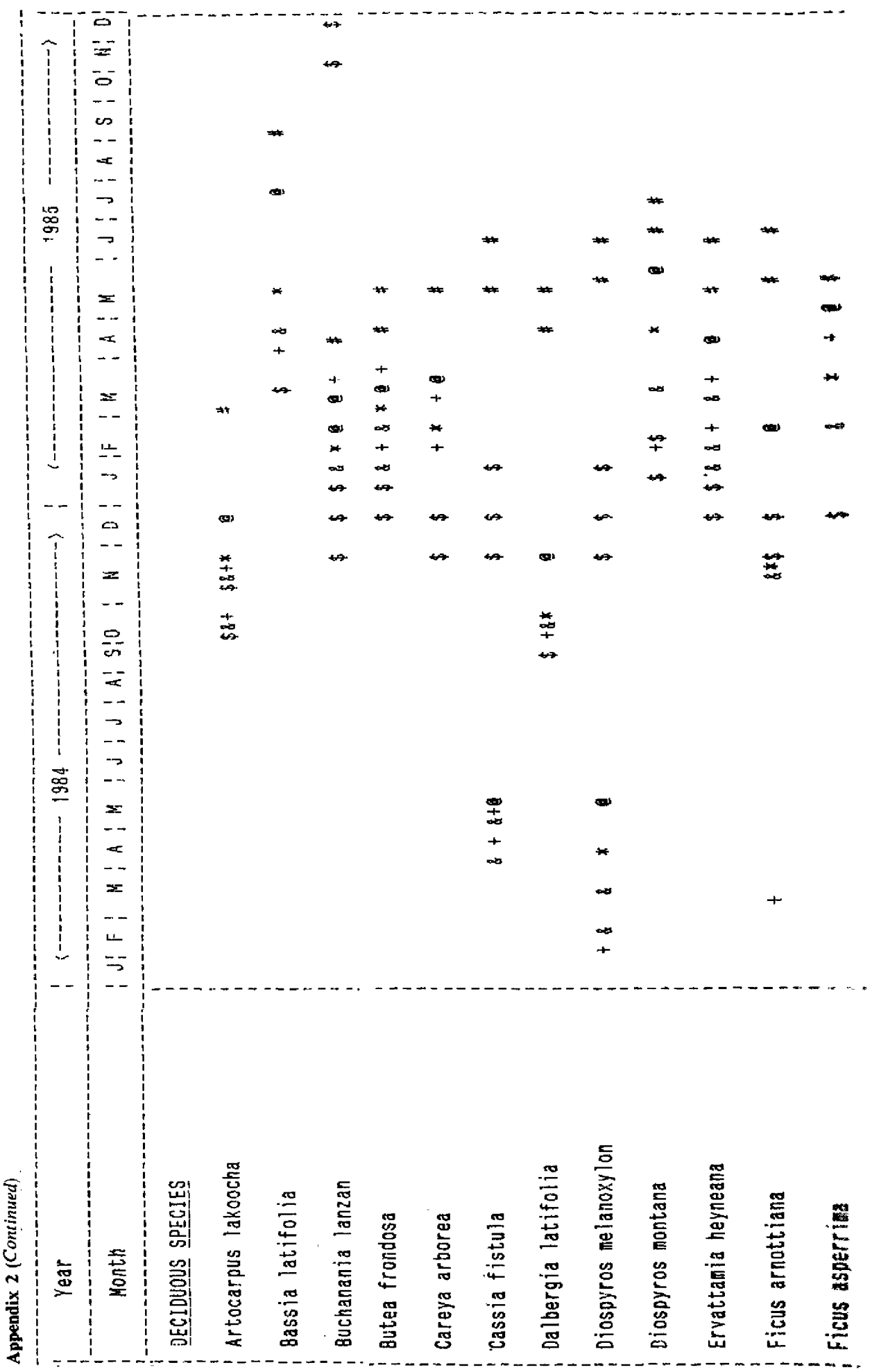




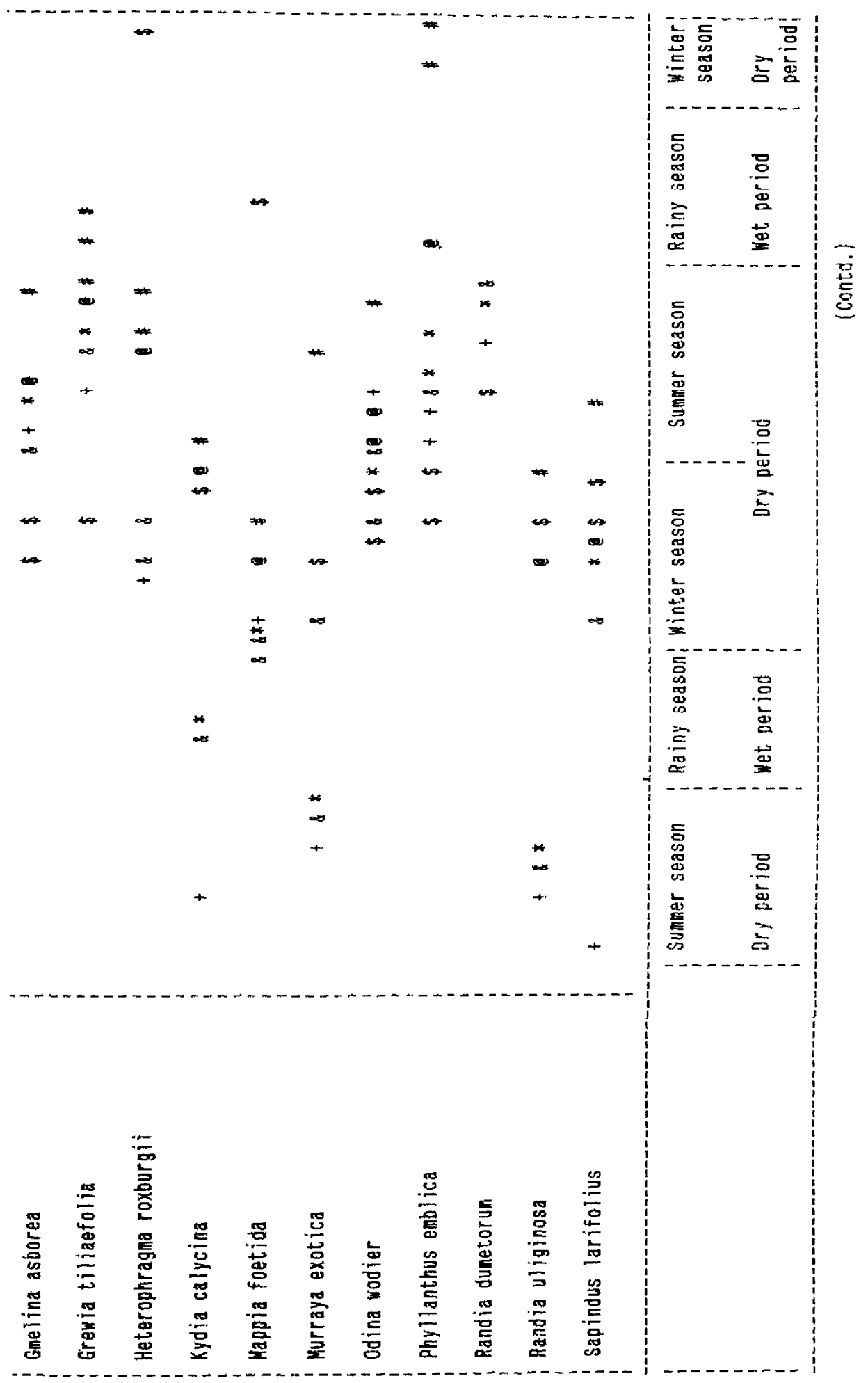




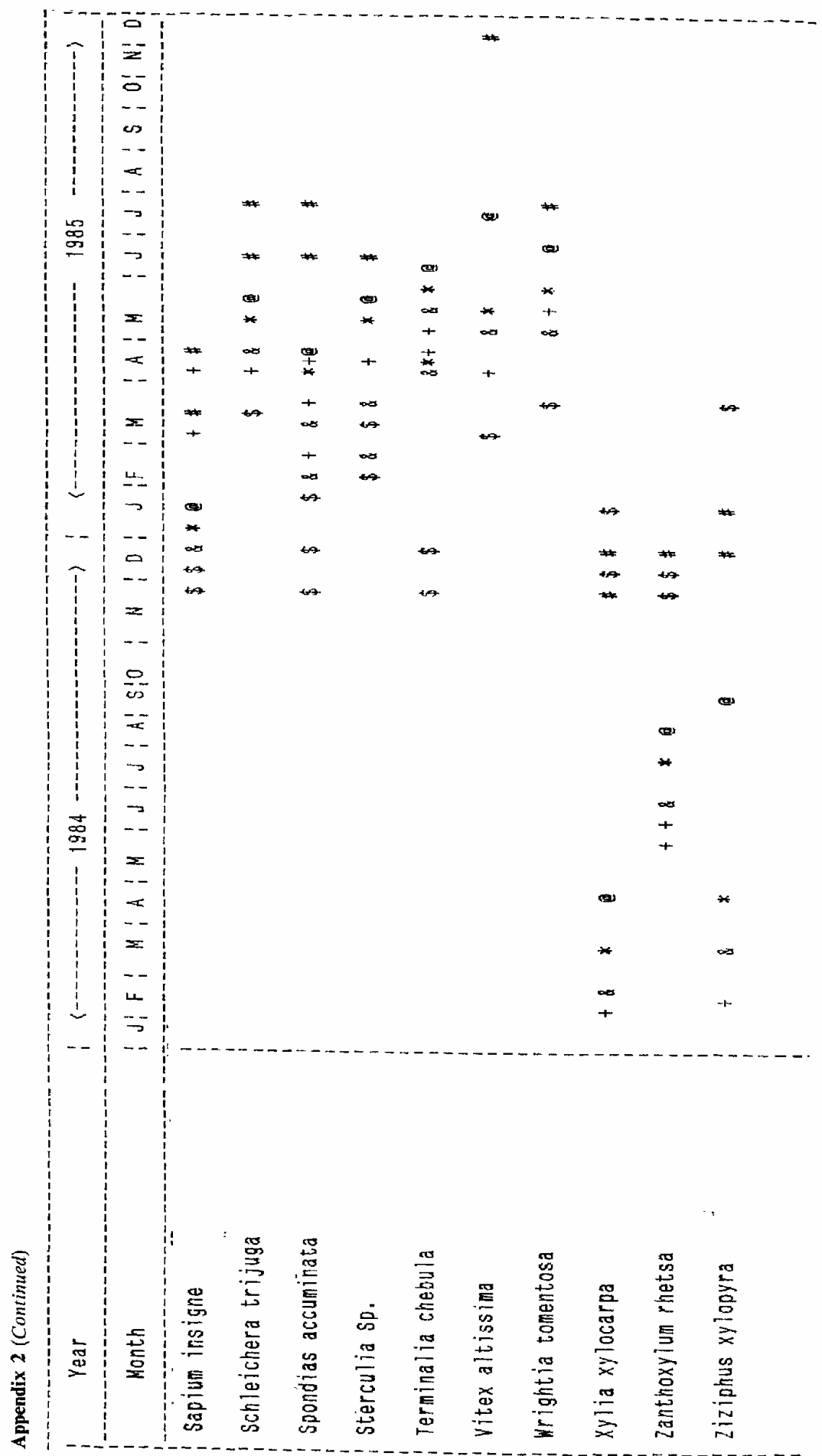




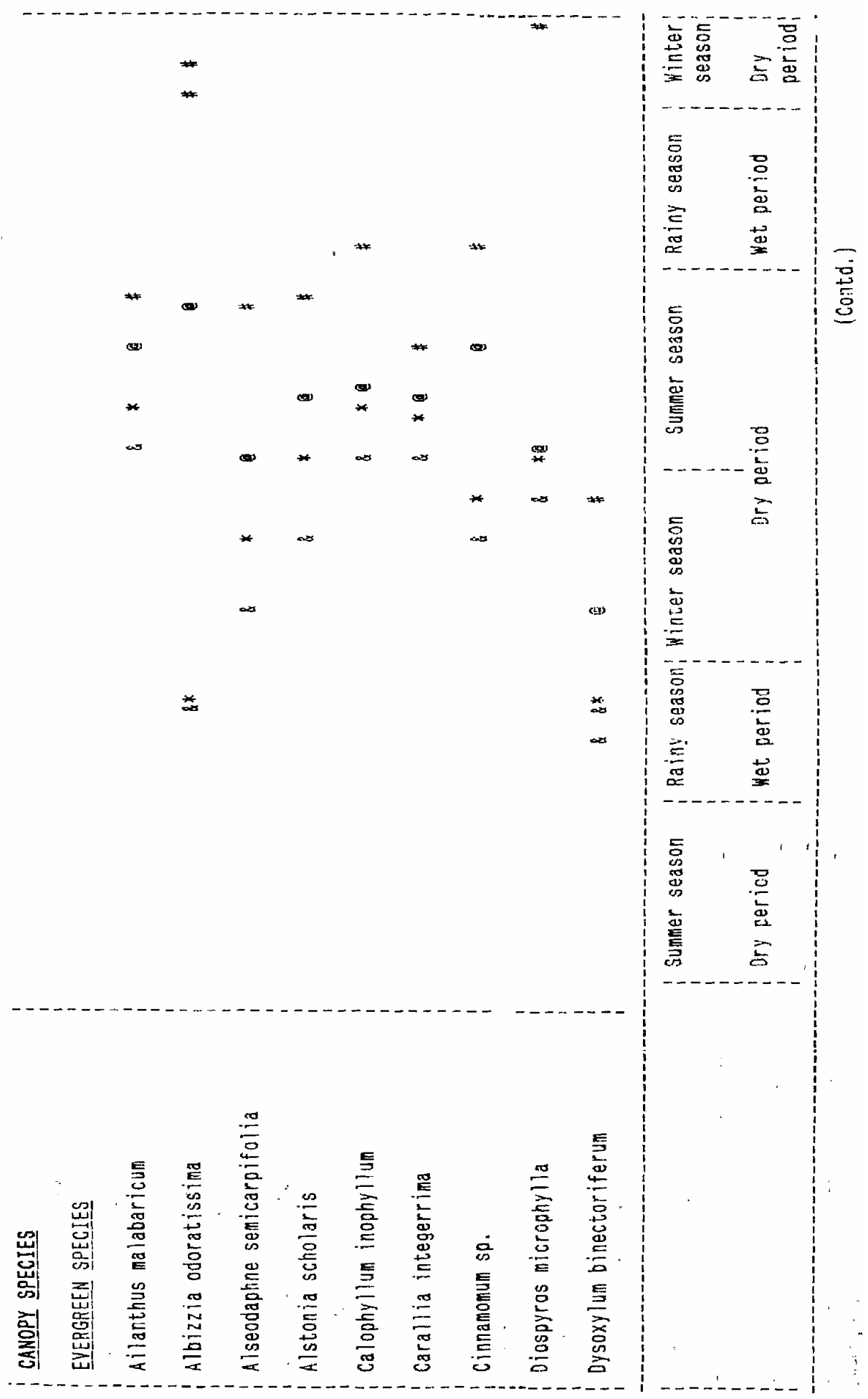




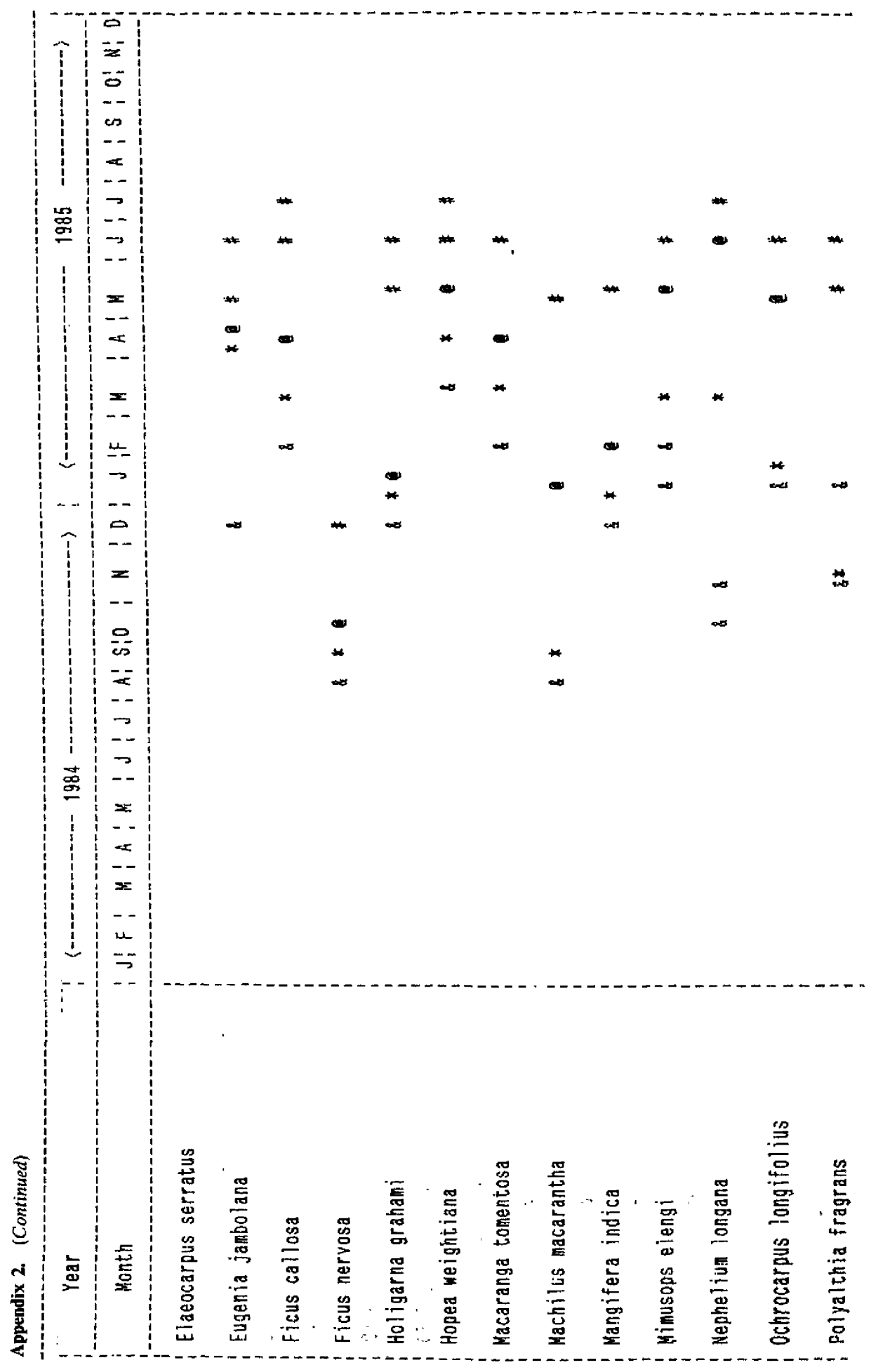




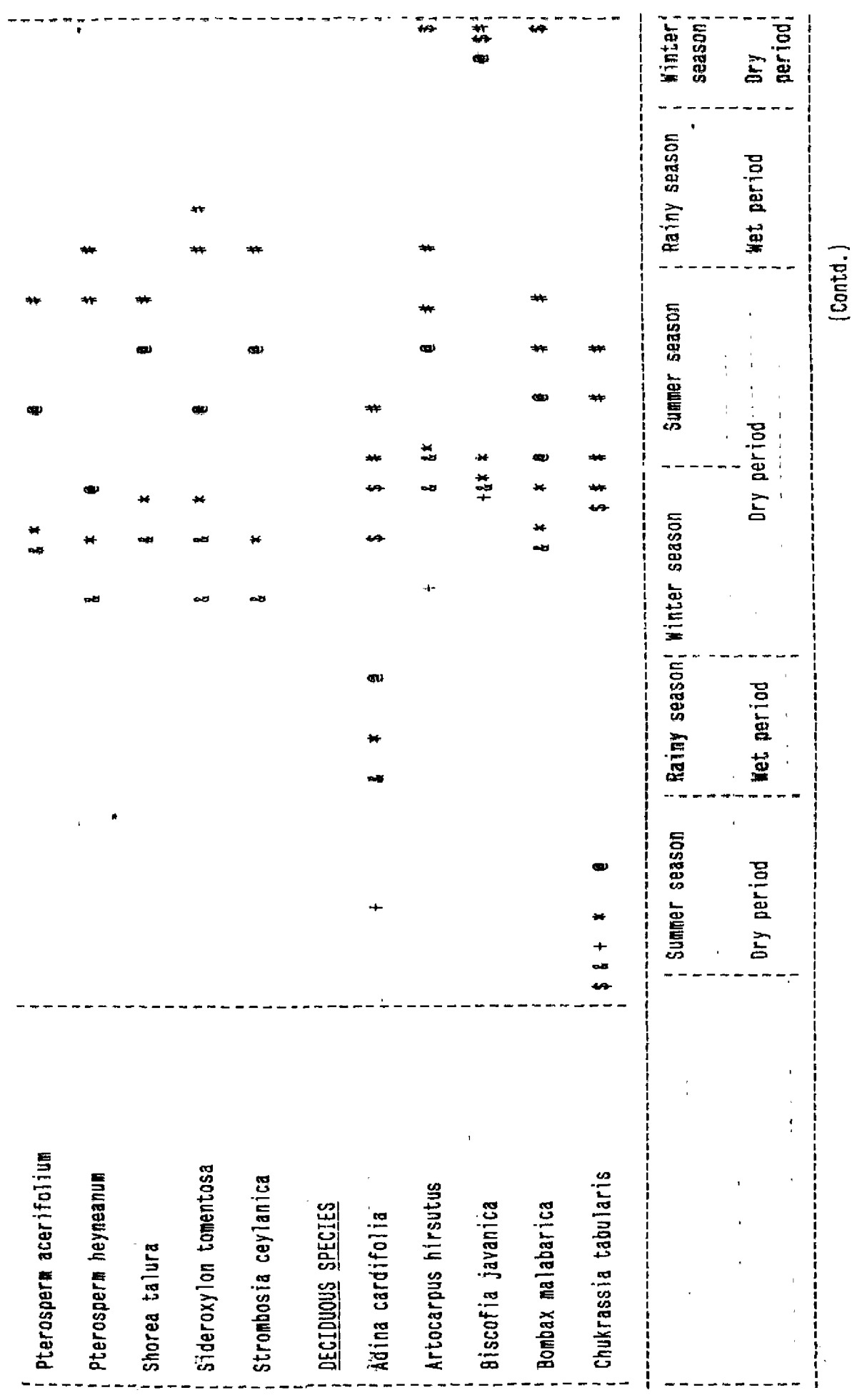


350

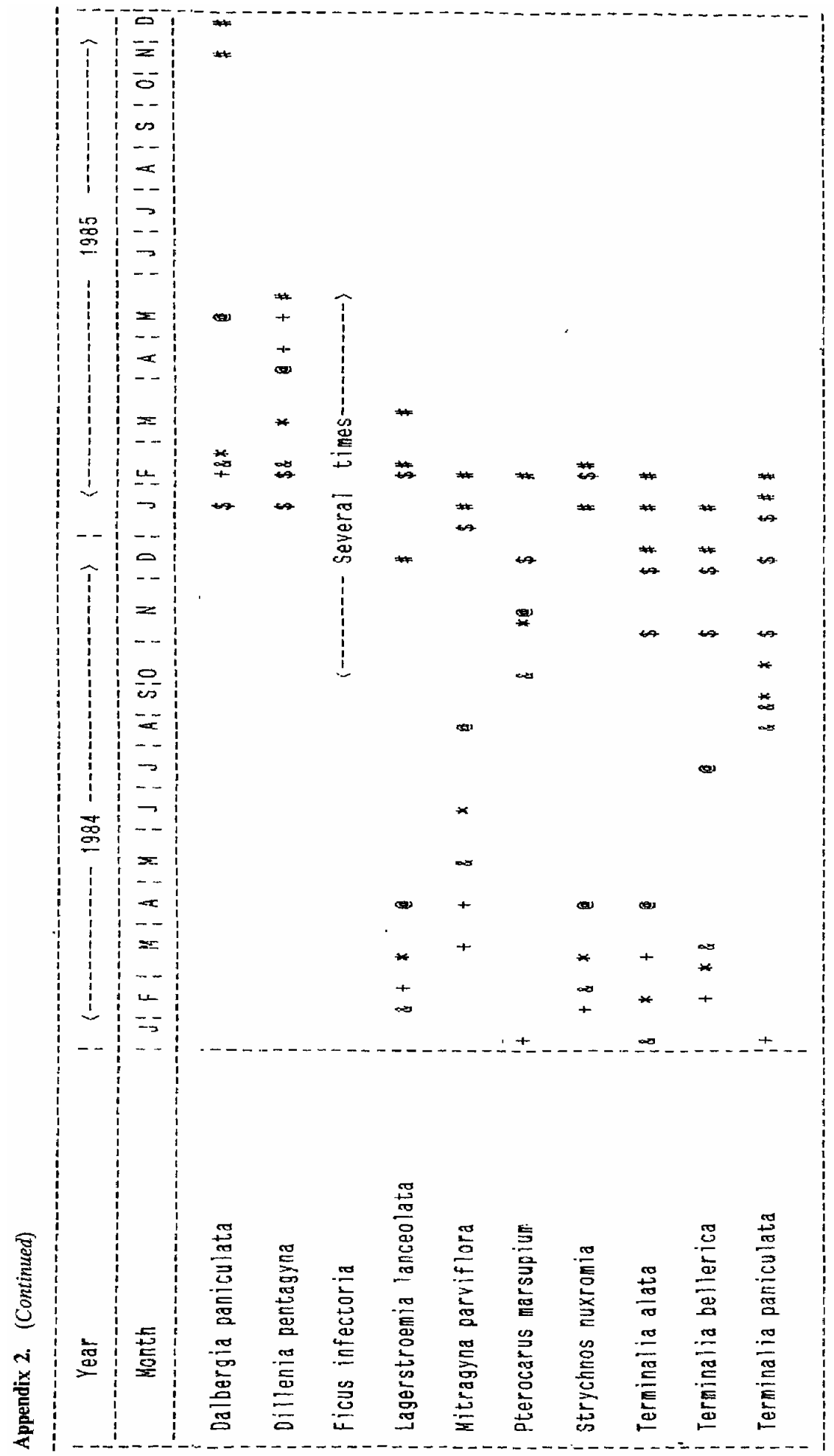




\section{References}

Alvim p de T 1964 Tree growth and periodicity in tropical climates; in The formation of wood in tropical trees (ed.) M H Zimmermann (New York: Academic press) pp 475-495

Alvim $\mathrm{p}$ de $\mathrm{T}$ and Alvim R 1978 Relation of climate to growth periodicity in tropical trees; in Tropical trees as living systems (eds) $\mathrm{P}$ B Tomlinson and $\mathrm{M} \mathrm{H}$ Zimmermann (Cambridge: Cambridge University Press) pp 445-464

Appanah S 1985 General flowering in climax rainforest of south-east Asia; J. Trop. Ecol. 1 225-240

Augspurger C K 1982 A cue for synchronous flowering; in The ecology of a tropical forest, seasonal rhythms and long term changes (eds) E G Leigh Jr, A Rand and D M Windsor (Washington: Smithsonian Institute Press) pp 133-150

Augspurger C K 1983 Seed dispersal of tropical tree, platypodium elegans, and the escape of its seedlings from fungal pathogens; J. Ecol. 71 759-771

Bhat D M 1990 Litter production and seasonality in tropical moist forest ecosystems of Uttara Kannada district, Karnataka; Proc. Indian Acad. Sci. (Plant Sci.) 100 139-152.

Boojh R and Ramakrishnan P S 1982 Growth strategy of trees related to successional status II. Leaf dynamics; J. For. Ecol. Manage. 4 375-386

Bullock S H and Bawa K S 1981 Sexual dimorphism and the annual flowering pattern in Jacarantia dolichanla (D smith) Woodson (Caricaceae) in Costa Rican rain forest; Ecology 62 1494-1504

Bullock S H and Solis-Magallanes J A 1990 Phenology of canopy trees of a tropical deciduous forest in Mexico; Biotropica 22 22-35

Coates-Estrada R and Estrada A 1986 Fruiting and frugivores at a strangler fig in the tropical rain forest of Los Tuxtlas, Mexico; J. Trop. Ecol. 2 349-357

Cooke T 1967 The flora of the presidency of Bombay (second reprinted edition) (Calcutta: Botanical Survey of India)

Daniels R J R, Hegde M and Gadgil M 1990 Birds of the man-made ecosystems: the plantation; Proc. Indian Acad. Sci. (Anim. Sci.) 99 79-89

Daubenmire R 1972 Phenology and other characteristics of tropical semideciduous forest in northwestern Costa Rica; J. Ecol. 60 147-170

Fogden M P L 1972 The seasonality and population dynamics of equitorial forest birds in Sarawak; Ibis 114 307-342

Foster R B 1982a Seasonal rhythm of fruit fall on Barro Colorado Island; in The ecology of a tropical forest, seasonal rhythms and long-term changes (eds) E G Leigh Jr, A S Rand and D M Windsor (Washington: Smithsonian Institution Press) pp 151-172

Foster R B 1982b Famine on Barro Colorado Island; in The ecology of a tropical forest, seasonal rhythms and long-term changes (eds) E G Leigh Jr, A S Rand and D M Windsor (Washington: Smithsonian Institution Press) pp 201-212

Frankie G W, Baker H G and Opler A P 1974a Tropical plant phenology: Application for studies in community ecology; in Phenology and seasonality modelling (ed.) H Lieth (Berlin: Springer-Verlag) pp 287-298

Frankie G W, Baker H G and Opler A P 1974b Comparative phenological studies of trees in tropical wet and dry forests in the low lands of Costa Rica; J. Ecol. 62 881-919

Hladik A 1978 Phenology of leaf production in rain forest of Gabon; in The ecology of arboreal folivores (ed.) G G Montgomery (Washington: Smithsonian Institute Press) pp 51-71

Janzen D H 1967 Synchronisation of sexual reproduction of trees within the dry season in Central America; Evolution 21 620-637

Janzen D H 1979 How to be a fig; Annu. Rev. Ecol. Syst. 10 13-51

Janzen D H 1983 Foodwebs: who eats what, why, how and with what effects in a tropical forest?; in Ecosystems of the World, 14A Tropical rainforest ecosystem (ed.) F. B. Golley (Amsterdam: Elsevier) pp 167-182

Kaul R B, Abbe E C and Abbe L B1986 Reproductive phenology of the Oak family (Fagaceae) in the low land rainforest of Borneo; Biotropica 18 51-55

Kramer P J and Kozlowski T T 1960 Physiology of trees (New York: McGraw Hill)

Kunkel-Westphal I and Kunkel P 1979 Litterfall in Guatemalan primary forest, with details of leaf shedding by some common species; J. Ecol. 67 287-302

Leigh E G Jr and Windsor D M 1982 Forest production and regulation of primary consumers on Barro Colorado Island; in The ecology of a tropical forest, seasonal rhythms and long-term changes (eds) E G Leigh Jr, A S Rand and D M Windsor (Washington: Smithsonian Institution Press) pp 111-122

Leighton M and Leighton D R 1983 Vertebrate responses to fruiting seasonality within a Bornean 
rainforest; in Tropical rainforest: ecology and management (eds) S L Sutton, T C Whitmore and A C Chadwick (Oxford: Blackwell) pp 181-196

Liberman D 1982 Seasonality and phenology in a dry tropical forest in Ghana; J. Ecol, 70 791-806

Lieth H 1974 Purposes of a phenology book; in Phenology and seasonality modelling (ed.) H Lieth (Berlin: Springer-Verlag) pp 3-19

Malaisse F 1974 Phenology of the Zambesian wood land area with emphasis on the miombo ecosystem; in Phenology and seasonality modelling (ed.) H Lieth (Berlin: Springer-Verlag) pp 269-286

Medway L 1972 Phenology of a tropical rainforest in Malaya; Biol. J. Linn. Soc. 4 117-146

Milton K, Windsor D M, Morrison D W and Estribi M A 1983 Fruiting phenologies of two neotropical Ficus species; Ecology 63 762-772

Monasterio M and Sarmiento G 1976 Phenological strategies of plant species in the tropical savanna and the semideciduous forest of the Venezuelan llanos; J. Biogeogr. 3 325-356

Opler P A, Frankie G W and Baker H G 1980 Comparative phenological studies of shrubs and treelets in wet and dry forests in the low lands of Costa Rica; J. Ecol. 68 167-186

Prasad N L N S 1983 Seasonal changes in the herd structure of Blackbuck; J. Bombay Nat. Hist. Soc. 80 549-554

Prasad S N and Hedge M 1986 Phenology and seasonality in the tropical deciduous forest of Bandipur, South India; Proc. Indian Acad. Sci. (Plant Sci.) 96 121-133

Prasad S N and Sharatchandra H C 1984 Primary production and consumption in the deciduous forest ecosystems of Bandipur in South India; Proc. Indian Acad. Sci. (Plant Sci.) 93 83-97

Proctor J, Anderson J M, Fogden S C L and Vallack H W 1983 Ecological studies in four contrasting lowland rainforests in Gunung Mulu National Park Sarawak. II. Litterfall, litter standing crop and preliminary observation on herbivory; J. Ecol. 71 261-283

Rai S N and Proctor J 1986 Ecological studies on four rainforests in Karnataka, India, II. Litterfall; $J$ Ecol. 74 455-463

Ralhan P K, Khanna R K, Singh S P and Singh J S 1985 Phenological characteristics of the shrub layer of Kumaun Himalayan forests; Vegetatio 63 113-119

Ralhan P K, Khanna R K, Singh S P and Singh J S 1985 Phenological characters of the tree layer of Kumaun Himalayan forests; Vegetatio 60 91-101

Rathcke B and Lacey E P 1985 Phenological patterns of terrestrial plants; Annu. Rev. Ecol. Syst, 16179 214

Salisbury F B and Ross C 1974 Plant physiology (New Delhi: Prentice Hall of India Pvt. Ltd.)

Santapau J 1962 Gregarious flowering of Strobilanthes and bamboos; J. Bombay Nat. Hist. Soc. 59688 695

Schaik C P, Van 1986 Phenological changes in Sumatran rain forest; J. Trop. Ecol. 2 327-347

Sharma V K 1970 A text book of plant physiology (Jallundar: Nagin and Co.)

Shukla R P and Ramakrishnan P S 1982 Phenology of trees in a sub tropical humid forest in north Eastern India; Vegetatio 49 103-109

Shukla R P and Ramakrishnan P S 1984 Leaf dynamics of tropical trees relation to successional status New Phytol. 97 697-706

Songwe N C, Fasehun F W and Okali D W 1988 Litterfall and production in a tropical rainforest southern Baakundu forest reserve, Cameroon; J. Trop. Ecol. 4 25-37

Steven D De, Windsor D M and Putz F E 1987 Vegatative and reproductive phenologies of a palm assemblage in Panama; Biotropica 19 342-356

Wada K 1983 Ecological adaptations in Rhesus monkeys at the Kumaun Himalaya; J. Bombay. Nat Hist. Soc. 59 469-498

Whitmore T C 1984 Tropical rainforests of the far East (Oxford: Clarendon Press) 